Review Article

\title{
Review of Experimental Studies on Application of FRP for Strengthening of Bridge Structures
}

\author{
Wenliang Hu (D), Yuan Li (D), and Haoyun Yuan (iD) \\ School of Highway, Chang'an University, Xi'an 710064, China \\ Correspondence should be addressed to Wenliang Hu; 2015021022@chd.edu.cn
}

Received 28 July 2020; Revised 3 September 2020; Accepted 21 December 2020; Published 30 December 2020

Academic Editor: Antonio Caggiano

Copyright (C) 2020 Wenliang $\mathrm{Hu}$ et al. This is an open access article distributed under the Creative Commons Attribution License, which permits unrestricted use, distribution, and reproduction in any medium, provided the original work is properly cited.

\begin{abstract}
In recent years, fiber-reinforced polymer (FRP) composites have been widely used as a new type of high-performance material in concrete structures. FRP composites have the advantages of high strength, light weight, and corrosion resistance. Based on existing studies in the literature, this paper reviews the development and applications of FRP materials for the strengthening and rehabilitation of bridge structures. The types and properties of FRP composites are summarized, and the applications and development of FRP sheets, FRP bars, FRP grids, and prestressed FRP tendons for bridge structures are discussed. Different types of FRP composites result in different failure characteristics and bearing capacities. Moreover, this paper covers the FRP strengthening methods and the response properties of the flexural performance, bonding performance, and ductility. Significant conclusions regarding the strengthening/repair of bridge structures with FRP composites are presented. The review details the current state of knowledge and research on strengthening bridge structures with FRP composites and is helpful for better understanding and establishing design criteria.
\end{abstract}

\section{Introduction}

In recent years, the degradation of concrete structures and steel structures has become increasingly severe [1-4], not only affecting the normal use and life of the structures but also introducing significant safety hazards. The performance degradation of bridge structures is directly affected by overload, corrosion, fatigue, and other adverse factors. Traditional concrete bridges and steel bridges quickly crack, peel, and collapse under harsh conditions, resulting in considerable economic losses. Figure 1 shows the damage to traditional asphalt pavement on a steel deck. The critical environmental and traffic conditions can affect the service life of traditional bridge decks. Typically, in such cases of damage to bridge decks, reinforcement materials such as FRP grids or steel grids are used to constrain the cracks and improve the stiffness of the bridge decks $[5,6]$. With the increasing demand for daily traffic, there are stricter requirements for the bridge erection speed, long-term reliability, overload resistance, and fatigue resistance.
Considering the safety and durability of the bridge and applying the necessary strengthening can improve the bearing capacity and stiffness of the bridge and extend its service life.

In general, steel bars are corrosion resistant owing to the alkaline concrete protective layer $(\mathrm{pH}>12)$; however, for bridges exposed to harsh conditions, the $\mathrm{pH}$ of the concrete decreases at a rate of $10 \%$ per year [8], and the steel bars corrode easily because of the acidification of the concrete. The corrosion of the steel bars in bridge decks is particularly severe, owing to the thinness of the protective layer and the permeation of deicing salt on the surface of the steel bars. Reinforced concrete bridge decks have been damaged to different degrees after using for years. There were approximately 600,000 bridges in service in the United States in the early 1990s, among which approximately 100,000 suffered serious corrosion problems involving steel bars, resulting in losses of $\$ 70$ billion (USD) per year [9]. Therefore, it is of great practical significance and research value to develop methods for reinforcing the damaged bridges and analyze 

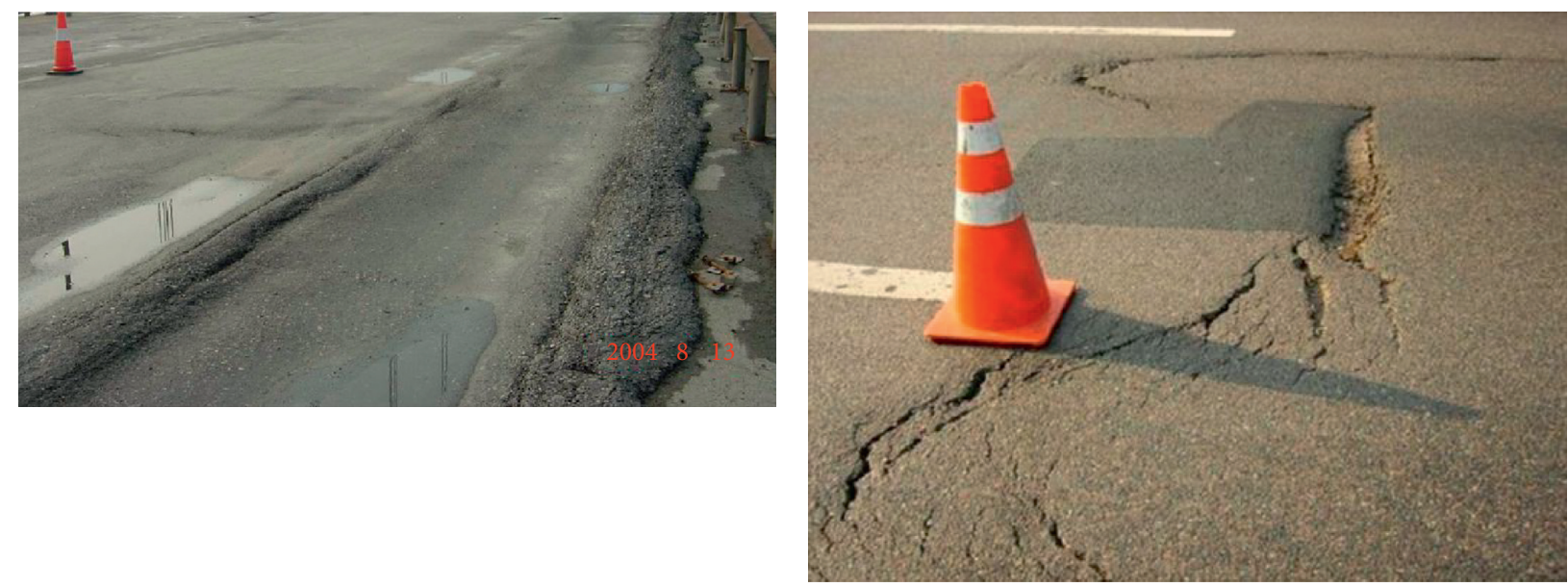

(a)

(b)

Figure 1: The damage of traditional asphalt pavement on a steel deck [7].

the mechanism and failure modes of the reinforced structures to improve the durability and sustainability of the existing bridge structures.

With the application and development of the traditional reinforcement technology, new building materials are produced, and new strengthening methods are developed. Using the fiber-reinforced polymer (FRP) to strengthen the concrete structures is an ideal method at present. The FRP is a new type of high-performance material that is composed of a fiber material and a matrix material mixed in a certain proportion and compounded via a certain process. The fibers are the main stress materials in the FRP and can be divided into long fibers and short fibers. Long fibers are mainly used in FRPs for engineering structures. The fiber plays the roles of stiffening and strengthening, and the resin plays the role of bonding the fiber. It can provide reinforcement via the shear force between the FRP sheets and the concrete. Recently, FRP has been widely used as a strengthening material in civil and construction engineering structures and repair engineering owing to its high strength, light weight, corrosion resistance, and fatigue resistance [10-13]. With the rapid development of FRP processing and molding technology, industrial forming processes such as pull-extrusion, winding, resin transfer molding, and vacuum import can produce large standardized FRP components with stable performance, providing the basic conditions for the wide application of FRP bridges. Currently, the FRPs commonly used in engineering structures are the carbon fiber-reinforced polymer (CFRP), glass fiberreinforced polymer (GFRP), basalt fiber-reinforced polymer (BFRP), and aramid fiber-reinforced polymer (AFRP) [14-17]. In structural engineering, the main product forms of FRP include laminates (sheets and plates), bars, cables, and grids [18-24]. The most common methods for strengthening using FRPs are externally bonded (EB) and near-surface mounted (NSM) reinforcements [25-28].

Some researchers investigated the shear and flexural performance of reinforced concrete beams strengthened with FRP materials, and they obtained some remarkable reinforced effect. Hawileh et al. [29] studied the effect of externally bonded CFRP sheets on the shear strength of shear-deficient reinforced concrete beams as attached to the beam's soffit. They indicated that the shear strength of reinforced concrete beams increased 10-70\% comparing with the control specimens. They also found that the flexural longitudinal reinforcement ratio played a significant role on the shear strength of reinforced beams. The effects of the ratio of longitudinal reinforcement and angle of application of CFRP sheets on the shear capacity of reinforced concrete beams with externally bonded CFRP sheets were investigated by Thamrin and Zaidir [30]. They showed that the angle of application of CFRP sheets $\left(45^{\circ}\right.$ and $\left.90^{\circ}\right)$ had almost no effect on the shear capacity of reinforced beams and different ratios of longitudinal reinforcement resulted in different failure modes. Three-sided or completely wrapped application of CFRP sheets may be necessary to prevent premature debonding failure for beams with higher values of the longitudinal reinforcement ratio. They also studied the shear strength of reinforced concrete beams with NSM bars [31]. The results demonstrated that the strengthened method can increase the shear capacity of reinforced beams significantly. In the meanwhile, Saqan et al. [32] indicated that both the strengthening methods of bonded CFRP sheets and NSM bars delayed the yielding of the internal steel reinforcement and resulted in an increase in the flexural strength and a decrease in stiffness degradation of the reinforced concrete frames. Hawileh et al. [33] studied the contribution of CFRP laminates on the shear strength of reinforced beams. The results demonstrated that the external flexural CFRP laminates can improve the shear strength of reinforced members as the vertical sides of reinforced members are not accessible. Moreover, using U-wrapped and completely wrapped CFRP sheets were two common wrapping configurations to improve the shear capacity of exsiting reinforced concrete structures [34]. Some concrete beams cannot strengthen with FRP laminates due to the narrow soffit. To overcome this obstacle, Salama et al. [35] investigated the feasibility of strengthening reinforced concrete beams in flexure by side-bonded CFRP sheets. They 
indicated that the strengthened method of side-bonded CFRP sheets can not only improve the flexural strength but also increase the shear strength of the reinforced members. In addition, strengthening with FRP bars or using FRP sheets can increase the flexural performance of reinforced concrete members [36-38].

With the increasing application of FRP strengthening materials, FRP materials have played a significant role in the modern construction industry. Although the use of FRP for strengthening concrete structures has made significant progress, few reviews of the strengthening of bridge structures have been published. Therefore, it was necessary to conduct a broad overview of the literature and the existing state of development regarding the application of FRP materials for strengthening bridge structures. This review focuses on the types of FRP materials, strengthening technologies, and performance indicators (bearing capacity, bonding, and ductility factor) from the viewpoint of FRPreinforced bridge structures. This review is believed to be useful for researchers and engineers, as it provides a deep understanding of the strengthening of bridge structures using FRP materials.

\section{Strengthening Materials}

FRP materials consist of two basic materials: fiber materials and matrix materials. The fiber materials mainly include carbon fiber, glass fiber, basalt fiber, and aramid fiber, and the matrix materials consist largely of resins. These two materials are mixed at a certain proportion, followed by a complex process, resulting in the formation of a new type of high-performance material: an FRP. Recently, FRPs have been widely used in civil engineering, particularly for structural reinforcement, owing to its light weight, high strength, and corrosion resistance [39-44].

\subsection{Types of FRPs}

2.1.1. CFRP. The CFRP is one of the earliest fiber composite materials used for bridge reinforcement and is widely used in fiber-reinforced composites because of its high tensile strength and elastic modulus. The main structural forms of CFRP are sheets, bars (strips and rods), and grids. The performance of CFRP bars in the transverse direction is inferior to that in the longitudinal direction, which results in premature failure in tensile tests [45]. The parameters of the CFRP bars are presented in Table 1. Pultruded CFRP strips are fabricated with unidirectional carbon fibers embedded in a vinylester resin matrix [42]. Information regarding CFRP strips and laminates is presented in Table 2. The CFRP grid is a new FRP configuration that has been used in the punching shear resistance of concrete slabs [46] and to reinforce steel deck plates for enhancing the stiffness [7]. Meisamit et al. [47] reinforced concrete slabs with CFRP grids and presented a theoretical method for predicting the loading capacity of the reinforced slabs by considering the real rupture mode. In [48], differences were observed between CFRP grids and steel reinforcements as strengthening materials for concrete slabs because of the linear elasticity of the CFRP grids. In comparison with the steel reinforcements, the elastic modulus, fatigue strength, and creep resistance of the CFRP were higher, and its expansion coefficient in the direction was lower $[41,49,50]$. A comparison of the mechanical properties and comprehensive performance indices indicated that the CFRP is more promising and advantageous than the steel reinforcements. CFRP has a high strength and elastic modulus and good corrosion resistance. However, carbon fibers are expensive owing to the lack of key technologies for raw silk production [51]. Additionally, components strengthened with CFRP are prone to brittle failure, particularly at high temperatures, and the tensile strength of the carbon fibers decreases significantly [52]. The elastic modulus and tensile strength of CFRP at $250^{\circ} \mathrm{C}$ were reduced by about $28 \%$ and $42 \%$, respectively, as compared to room temperature [53]. Moreover, CFRP exhibits electrical conductivity; thus, it cannot be used in applications requiring insulation $[54,55]$.

2.1.2. GFRP. GFRP was widely applied in civil engineering owing to its smooth surface, excellent permeability resistance, corrosion resistance (to acid, alkali, seawater, and fresh water), and high cost-effective performance [58]. GFRP is a composite engineering material with the reinforced material of glass fiber and the polymer matrix of synthetic resin. Owing to its low cost and good corrosion resistance, GFRP is often used as a replacement for steel to repair damaged concrete structures [59, 60]. Researchers have proven that steel is an isotropic material, and it is very prone to electrochemical corrosion and yield; in contrast, GFRP is an anisotropic material with excellent tension performance [61-64]. Glass fiber is formed by melting glass and drawing, and it is inexpensive. Moreover, compared with using steel, the use of GFRP for strengthening concrete bridges at the characterization level of the cradle-to-grave scenario can reduce global warming, photochemical oxidant creation, acidification, and eutrophication by $25 \%, 15 \%, 5 \%$, and $50 \%$, respectively [65]. However, the elastic modulus of GFRP is low, the creep is large, and the durability is poor. Additionally, GFRP is highly sensitive to alkaline environmental conditions [51]. The properties of GFRP are presented in Table 3.

2.1.3. BFRP. Basalt fiber is an inorganic fiber material derived from the raw material of the glassy basalt mine formed by volcanic eruption, which is stretched by a spinneret after being crushed and fused at a high temperature $\left(1400^{\circ} \mathrm{C}\right)[67,68]$. The color of basalt fiber is dark brown, similar to carbon fiber. Basalt fiber has high strength, good modulus, excellent stability, high temperature resistance, and chemical resistance; additionally, it is easily fabricated, nontoxic, nonhazardous, ecofriendly, and inexpensive [69-74]. Basalt fiber is six times less expensive than carbon fiber because of the availability of the raw materials and the simple manufacturing process [71]. BFRP shows stable mechanical properties under a high-temperature environment. In experimental strength tests of basalt fibers, carbon fibers, and glass fibers at 100, 
TABle 1: Physical properties of CFRP bars [45].

\begin{tabular}{|c|c|c|c|c|c|c|}
\hline Types & $\begin{array}{c}\text { Nominal diameter } \\
(\mathrm{mm})\end{array}$ & $\begin{array}{l}\text { Nominal area } \\
\left(\mathrm{mm}^{2}\right)\end{array}$ & $\begin{array}{l}\text { Guaranteed tensile strength } \\
(\mathrm{MPa})\end{array}$ & $\begin{array}{c}\text { Max. tensile load } \\
(\mathrm{kN})\end{array}$ & $\begin{array}{l}\text { Modulus of elasticity } \\
(\mathrm{GPa})\end{array}$ & $\begin{array}{l}\text { Ultimate } \\
\text { strain (\%) }\end{array}$ \\
\hline \multirow{3}{*}{$\begin{array}{l}\text { CFRP } \\
\text { bars }\end{array}$} & 6 & 31.67 & 2241 & 71 & 124 & 1.81 \\
\hline & 10 & 71.26 & 2172 & 154 & 124 & 1.73 \\
\hline & 13 & 126.7 & 2068 & 262 & 124 & 1.67 \\
\hline
\end{tabular}

TABle 2: Physical properties of CFRP strips and laminates.

\begin{tabular}{|c|c|c|c|c|c|c|c|}
\hline Types & $\begin{array}{l}\text { Width } \\
(\mathrm{mm})\end{array}$ & $\begin{array}{l}\text { Length } \\
(\mathrm{mm})\end{array}$ & $\begin{array}{l}\text { Thickness } \\
(\mathrm{mm})\end{array}$ & $\begin{array}{c}\text { Tensile strength } \\
(\mathrm{MPa})\end{array}$ & $\begin{array}{c}\text { Elastic modulus } \\
(\mathrm{GPa})\end{array}$ & $\begin{array}{c}\text { Ultimate } \\
\text { strain (\%) }\end{array}$ & $\begin{array}{l}\text { Decomposition } \\
\text { temperature }\left({ }^{\circ} \mathrm{C}\right)\end{array}$ \\
\hline $\begin{array}{l}\text { CFRP sheet } \\
\text { [56] }\end{array}$ & - & - & 0.12 & 4100 & 231 & 1.7 & - \\
\hline $\begin{array}{l}\text { CFRP strips } \\
{[42]}\end{array}$ & 10 & - & 1.4 & 2850 & 168 & 1.6 & 380 \\
\hline $\begin{array}{l}\text { CFRP plate } \\
{[57]}\end{array}$ & 20 & $90-180$ & 2 & 4100 & 256 & - & - \\
\hline
\end{tabular}

TABle 3: Properties of GFRP.

\begin{tabular}{|c|c|c|c|c|c|c|}
\hline Types & $\begin{array}{c}\text { Nominal diameter } \\
(\mathrm{mm})\end{array}$ & $\begin{array}{c}\text { Thickness } \\
(\mathrm{mm})\end{array}$ & $\begin{array}{l}\text { Width } \\
(\mathrm{mm})\end{array}$ & $\begin{array}{c}\text { Tensile strength } \\
(\mathrm{MPa})\end{array}$ & $\begin{array}{c}\text { Tensile modulus } \\
(\mathrm{GPa})\end{array}$ & $\begin{array}{l}\text { Fracture } \\
\text { strain (\%) }\end{array}$ \\
\hline \multirow{3}{*}{ GFRP bars [66] } & 8 & - & - & $1175 \pm 16$ & $49 \pm 3$ & $2.5 \pm 0.4$ \\
\hline & 10 & - & - & $1241 \pm 67$ & $53 \pm 3$ & $2.3 \pm 0.3$ \\
\hline & 12 & - & - & $1166 \pm 60$ & $53 \pm 5$ & $2.4 \pm 0.2$ \\
\hline \multirow{2}{*}{ GFRP bars [16] } & 12 & - & - & 1113 & 62.3 & 1.8 \\
\hline & 16 & - & - & 1102 & 61.2 & 1.8 \\
\hline $\begin{array}{l}\text { GFRP plate with a transverse surface } \\
\text { mat [17] }\end{array}$ & - & 4 & 50 & 516 & 33 & 1.60 \\
\hline $\begin{array}{l}\text { GFRP plate without a transverse } \\
\text { surface mat [17] }\end{array}$ & - & 4 & 50 & 722 & 51 & 1.42 \\
\hline
\end{tabular}

$200,400,600$, and $1200^{\circ} \mathrm{C}$, the strengths of all three fibers decreased above $200^{\circ} \mathrm{C}$; however, while the strengths of the carbon fiber and glass fiber decreased significantly, the strength retention rate of the basalt fiber was $>90 \%$ at $600^{\circ} \mathrm{C}$ [75]. Moreover, as the temperature increased from 100 to $250^{\circ} \mathrm{C}$, the tensile strength of the basalt fiber increased by $30 \%$, but that of the glass fiber decreased by $23 \%$. In $70^{\circ} \mathrm{C}$ hot water, the strength of the basalt fiber was maintained for $1200 \mathrm{~h}$, but the glass fiber lost strength

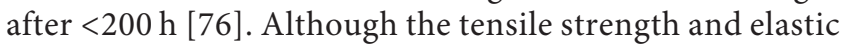
modulus of basalt fiber are lower than those of carbon fiber, basalt fiber has advantages with regard to the ductility, cost, corrosion resistance, and high-temperature resistance. Sim et al. [75] examined the four-point loading failure of 10 basalt fiber-reinforced concrete beams. Their experiments revealed that the yielding strength and ultimate strength increased by $15 \%$ and $0 \%$ with one layer of basalt fiber sheet, $26 \%$ and $27 \%$ with two layers, and $16 \%$ and $29 \%$ with three layers, respectively.

Basalt fiber can be used as reinforcement to produce various forms of basalt composite materials. Compared with other fiber materials, basalt fiber has many advantages and special properties.
(1) Basalt fiber is manufactured using natural rock as a raw material and is a pure natural inorganic material with excellent mechanical properties, ideal durability, and good adaptability to various environments.

(2) With rich raw materials, basalt fiber has a low cost. BFRP is expected to approach the level of GFRP at the various properties in future, which can break through the price bottleneck in FRP application.

(3) Basalt fiber is particularly suitable for seismic structures with a high ultimate strain and good ductility.

(4) Basalt fiber has a good fatigue resistance, strong adhesion with resin, and excellent compatibility with metal, plastic, and carbon fiber.

However, basalt fiber also has shortcomings, such as poor shear performance, brittleness, and a low elastic modulus.

2.1.4. AFRP. AFRP is a high-strength aromatic polyamide synthetic organic fiber with light weight, high strength, and good corrosion and heat resistance [77-79]. AFRP sheets are 
made of aramid fibers arranged in one or two directions, and they are light, soft, durable, insulating, and corrosion resistant. Compared with GFRP, AFRP has higher strength, higher elastic modulus, better heat resistance, and lower density [80]. The tensile strength of AFRP is nearly five and two times higher than that of steel and GFRP, respectively [81]. Additionally, compared with CFRP, AFRP is easier to fabricate, has a higher alkaline resistance, and is less expensive [82]. However, AFRP has limited applicability to civil engineering and building construction owing to its low compressive strength and high tensile strength [80].

2.1.5. Hybrid Fiber-Reinforced Polymer (HFRP). Hybrid fiber is a composite material with more than two types of fibers reinforcing the same matrix, which can improve the comprehensive mechanical properties of the single fiber material, increase the fiber utilization rate, and reduce the cost [67]. Polyolefin fiber is the most popular synthetic fiber used for strengthening concrete members and is fabricated with organic polymers polymerized by olefins via chain growth [83]. There are advantages of suppressing the development of shrinkage cracks, preventing the formation of internal cracks, increasing the ductility, and reducing the segregation, balling, and bleeding of concrete [84]. Hybrid composites with carbon fiber and polyethylene fiber were investigated by Park and Jang [41]. They used the open leaky mold method to fabricate the hybrid fiber and found that the position of the reinforcing fiber significantly affected the mechanical properties of the hybrid fiber. The HFRP exhibited the highest flexural strength with the carbon fiber at the outermost layer, owing to the maximum magnitudes of the compressive and tensile stress at the outermost layer. The hybrid fiber sheet was fabricated vertically with glass and aramid fibers, and the glass fiber was the main stress-bearing fiber. Eswari [85] proved that the strength, crack propagation, and ductility of HFRP were better than those of the single fibers. The hybrid fiber exhibited excellent performance and reduced the costs [86].

\subsection{Products of FRP}

2.2.1. FRP Sheets. FRP sheets are the most widely used form in the building reinforcement. They are fabricated with long, continuous fibers and are typically used for the reinforcement of structural members, affixed to the surface of the concrete members after being impregnated with resin. FRP sheets generally only bear unidirectional stretching. The width of FRP sheets can be $20,30,50$, or even $100 \mathrm{~cm}$; the length is between 50 and $100 \mathrm{~m}$, which is sufficient to avoid lapping. The surrounding environments of FRP sheets determine their properties. The effects of fresh water, seawater, a negative temperature $\left(-15.5^{\circ} \mathrm{C}\right)$, and freezethaw cycling on the flexural performance were examined, and the degree of degradation decreased in the following order: negative temperature $\left(-15.5^{\circ} \mathrm{C}\right)>$ freeze-thaw cycling $>$ fresh water $>$ seawater [87]. Moreover, Gharachorlou and Ramezanianpour [88] reported that a larger number of FRP layers resulted in better durability, as the reinforced concrete members with FRP sheets were exposed to the saline solution. In the saline solution, the degradation of the properties mainly depended on the humidity; meanwhile, the salt crystals increased the degree of degradation owing to the crack expansion [89]. The mechanical performance of GFRP sheets decreased as the temperature increased from 35 to $65^{\circ} \mathrm{C}$ in a $\mathrm{NaCl}$ solution [90]. FRP sheets are commonly applied for strengthening beams, slabs, and columns. They are easily bonded with the surfaces of concrete structures, which can increase the flexural strength and shear strength of the concrete members.

2.2.2. FRP Bars. FRP bars are fabricated via a unidirectional pultrusion molding process, via the mixing of unidirectional long fibers and resin. The surface of the FRP bar can be treated as a ribbed bar to enhance the bonding capacity, in contrast to that of a round bar [91]. The FRP cable is a wirelike FRP product formed via unidirectional weaving of continuous long fibers followed by solidification with a small amount of resin or without resin. FRP bars and cables can replace steel bars and prestressed bars in reinforced concrete structures and can also be used in long-span cable support structures, tensioned structures, and suspended cable structures.

CFRP bars are composed of carbon fibers and a resin matrix; thus, carbon fibers play an important role in strengthening, and resin is mainly used to bond the fibers. The volume content of CFRP bars is between $60 \%$ and $65 \%$, and as the fiber content increases, the strength increases, but extrusion molding becomes more difficult. The cross sections of CFRP bars are generally round, and the shapes of the surface mainly include smooth, nicked, and wrapping. Different surface treatment methods result in different bonding performances between the CFRP bars and concrete. The diameter of most CFRP bars is 5-12 $\mathrm{mm}$, and the mechanical properties of FRP bars and prestressing steel are presented in Table 4. Examples of the GFRP and BFRP bars are presented in Figure 2.

Compared with steel strands, CFRP bars generally have the following characteristics [93-95]:

(1) The longitudinal tensile strength and compressive strength of CFRP bars are higher, but the transverse strengths are lower. CFRP bars are typically brittle and exhibit obvious anisotropy, and there is no obvious yield stage before the tensile strength is reached. Additionally, the ultimate strain is small.

(2) The low elastic modulus of CFRP bars results in excessive deflection and wide cracks of concrete structures with CFRP bars, which can be avoided by applying prestress.

(3) The density of CFRP bars is only approximately $1 / 4$ of that of the steel strands, which is beneficial for reducing the weight of the structure and convenient for installation.

(4) The coefficient of thermal expansion of CFRP bars is significantly different from that of concrete. 
TABLE 4: The mechanical properties of FRP bars and prestressing steel [92].

\begin{tabular}{|c|c|c|c|c|}
\hline & AFRP & CFRP & GFRP & Prestressing steel \\
\hline Fiber volume ratio & 0.65 & 0.65 & 0.55 & - \\
\hline Density $\left(\mathrm{g} / \mathrm{cm}^{3}\right)$ & 1.28 & 1.53 & 2.1 & 7.85 \\
\hline Longitudinal tensile strength $(\mathrm{GPa})$ & $1.25-1.4$ & $2.25-2.55$ & 1.08 & 1.86 \\
\hline Transverse tensile strength $(\mathrm{MPa})$ & 30 & 57 & 39 & 1860 \\
\hline Longitudinal E-modulus (GPa) & $65-70$ & $142-150$ & 39 & 210 \\
\hline Transverse E-modulus (GPa) & 5.5 & 5.7 & 8.6 & 210 \\
\hline In-plane shear strength $(\mathrm{MPa})$ & 4.9 & 71 & 89 & - \\
\hline In-plane shear modulus (GPa) & 2.2 & 7.2 & 3.8 & 72.1 \\
\hline Major Poisson's ratio & $0.34-0.6$ & 0.27 & 0.28 & 0.3 \\
\hline Minor Poisson's ratio & 0.02 & 0.02 & 0.06 & 03 \\
\hline Bond strength (MPa) & $10-13$ & $4-20$ & - & $6.6-7.1$ \\
\hline Maximum longitudinal strain (\%) & $2.0-3.7$ & $1.3-1.5$ & 2.8 & 4.0 \\
\hline Maximum transverse strain (\%) & - & 0.6 & 0.5 & 4.0 \\
\hline Longitudinal compressive strength (MPa) & 335 & 1440 & 620 & 1860 \\
\hline Transverse compressive strength $(\mathrm{MPa})$ & 158 & 228 & 128 & 1860 \\
\hline Longitudinal thermal expansion coefficient $\left(\times 10^{-6} \cdot 1 /^{\circ} \mathrm{C}\right)$ & -2 & -0.9 & 7 & 11.7 \\
\hline Transverse thermal expansion coefficient $\left(\times 10^{-6} \cdot 1 /{ }^{\circ} \mathrm{C}\right)$ & 60 & -27 & 21 & 11.7 \\
\hline
\end{tabular}

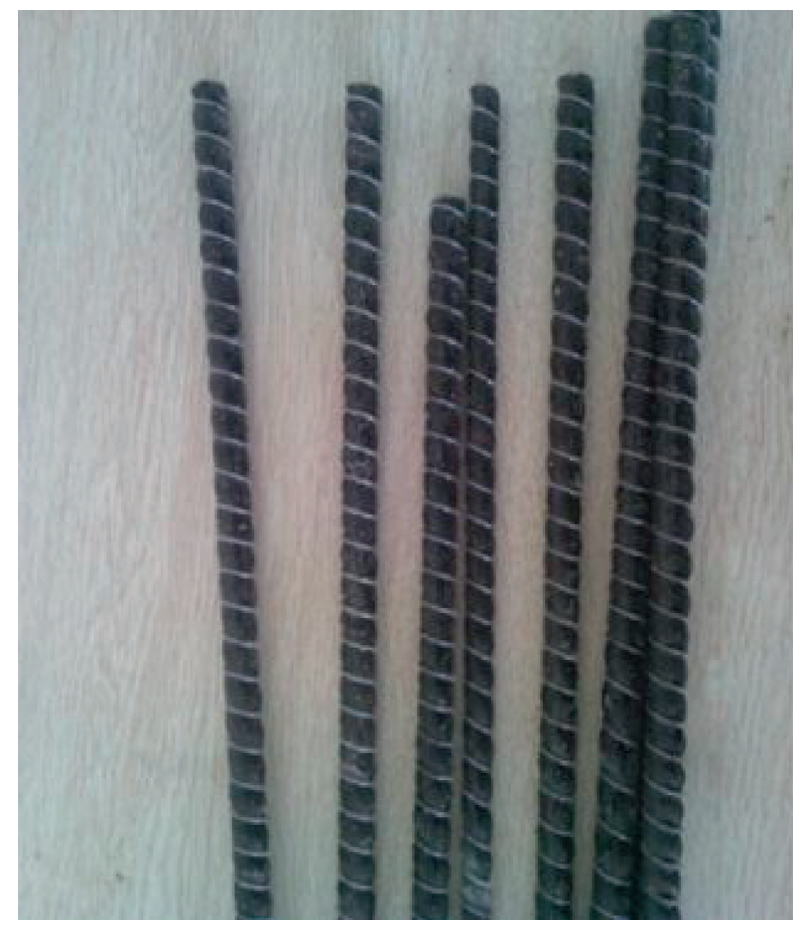

(a)

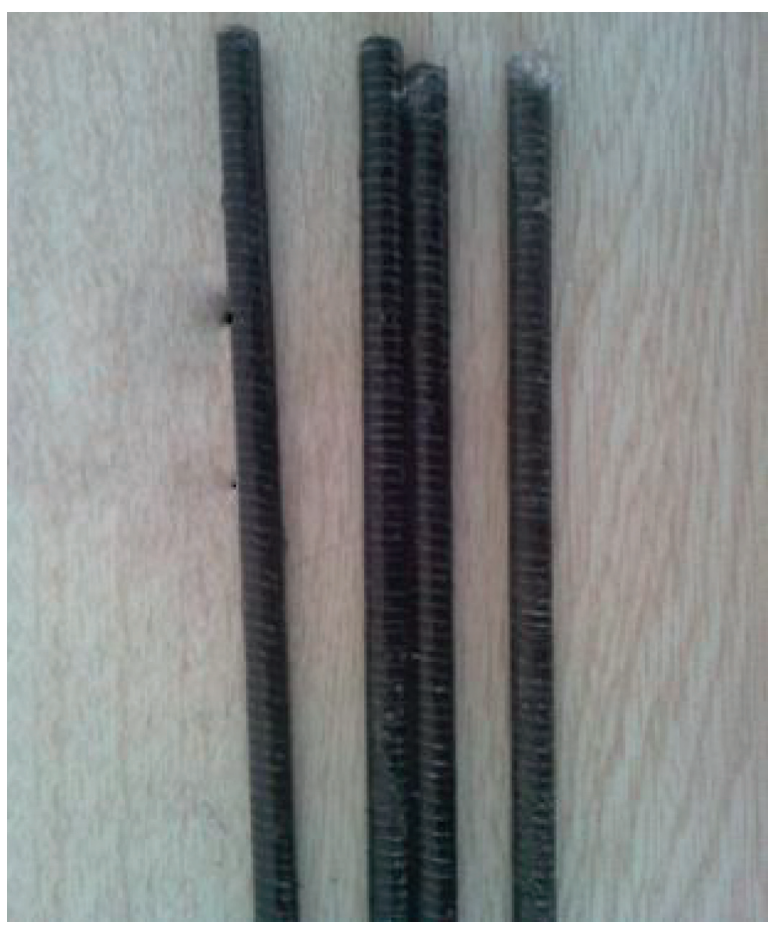

(b)

FIGURE 2: FRP bars [93]: (a) GFRP bars; (b) BFRP bars.

Additionally, the axial coefficient of thermal expansion is small, which is beneficial for adaptation to the climate.

(5) CFRP bars can be used in corrosive environments for a long time because of their excellent corrosion resistance; moreover, they can reduce the maintenance cost.

(6) Compared with steel, CFRP bars can reduce the effects of electromagnetic fields on instruments inside the structure owing to their excellent antimagnetic performance.

(7) The fatigue resistance of CFRP bars is better than that of steel, and CFRP bars can satisfy the fatigue requirements of building structures.

2.2.3. FRP Grids. FRP grids (Figure 3) can be formed by weaving long fiber bundles perpendicular to each other at certain intervals and then solidified with resin. For the long 


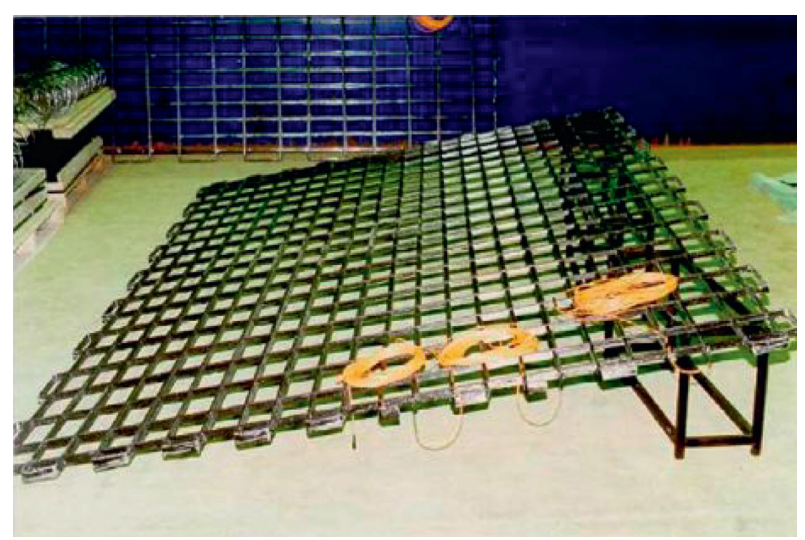

Figure 3: Overview of FRP grids [48].

continuous fiber, carbon fiber, glass fiber, basalt fiber, and aramid fiber are often used. FRP grids can replace the steel mesh, and an FRP cage can replace the steel cage.

According to the products on the market, FRP grids are categorized as follows:

(1) According to their shape, they can be classified as single reinforced composite-type or whole-type. In the former case, FRP bars form a grid via cross lap joints. In the latter case, the fibers are directly solidified as fiber bundles, and the resin is laid into a mesh.

(2) According to the types of reinforced fibers, FRP grids are divided into BFRP grids, CFRP grids, GFRP grids, and AFRP grids.

(3) According to the mesh shape, they can be classified into bidirectional square grids and tridirectional equilateral triangle grids.

(4) According to the stress direction, there are isotropic strengths and different strengths in different directions (i.e., the fiber contents in two or three directions are different).

(5) According to their appearance, FRP grids are classified as embossed type or smooth type.

The main control parameters of FRP grids include the mesh size $\left(50 \times 50 \mathrm{~mm}^{2}, 100 \times 100 \mathrm{~mm}^{2}, 150 \times 150 \mathrm{~mm}^{2}\right.$, $50 \times 100 \mathrm{~mm}^{2}$, and $\left.100 \times 150 \mathrm{~mm}^{2}\right)$, mesh width $(0.5,1,1.5$, and $2 \mathrm{~m}$ ), and mesh thickness $(0.5,1,1.5,2,3,4$, and $5 \mathrm{~mm})$. The mechanical properties of FRP materials are presented in Table 5.

\section{FRP Strengthening Methods for Bridge Structures}

Concrete bridges, which include reinforced concrete bridges and prestressed concrete bridges, are widely used worldwide. At present, most of these bridges are subject to multiple types of damage; thus, the design grade of the original bridges does not satisfy the current requirements, and reinforcement is needed. Among the FRP strengthening methods, the EB FRP technique (bonding CFRP to the surface of the concrete) was first proposed [97]. Recently, with the development of the strengthening technique, the near-surface mounted (NSM) FRP method was proposed, which involves bonding the FRP bars/strips/rods in the precutting grooves on the surface of the concrete cover. In comparison with the EB FRP technique, NSM FRP exhibits a higher strengthening efficiency and better protection against environmental agents, vandalism, impact loads, and exposure to high temperatures $[98,99]$. The details of the reinforcement methods for concrete bridges are presented in the following sections.

3.1. Externally Bounded Steel Plate. The reinforced method of the externally bounded steel plate involves attaching a steel plate to the tensile part of the member with a special building structure adhesive; thus, the steel plate and the original member are combined, forming a single structure. They bear the load together, increasing the bearing capacity of the members. This method has the advantage of a short construction period; moreover, it consumes little space, hardly alters the shapes of the members, and significantly improves the bearing capacities of the members and the performance in the normal use stage. However, it also has disadvantages; for example, it can increase the weight of the structure, and the steel plate can corrode easily.

In the past, the common reinforcement method for bridge decks has involved applying EB steel plates or reinforcement at the bottom of the bridge decks. The EB steel plate reinforcement technology was first used in South Africa and France [100]. Subsequently, studies on such reinforcement methods were performed, revealing that the concrete structure strengthened with steel plates was prone to debonding failure because of the stress concentration at the ends of the reinforced steel plates [101, 102]. In 1988, Jones et al. [103] improved the anchorage measures for the end of the steel plate to prevent debonding failure. Moreover, another reinforcement method was proposed: thickening the section of the decks for reinforcement; however, this method resulted in a large construction area; additionally, it is difficult to reinforce the bridge decks. Steel is used in these two reinforcement methods, which is not only heavy but also has poor corrosion resistance. Therefore, there are still obvious defects and low sustainability in practical application [104].

3.2. Externally Bonded FRP Sheets. At the beginning of the application of FRP in reinforcement, the common reinforcement method is to bond the FRP sheets or other laminates on the tensile area of the concrete beam, providing a passive reinforcement. Although this strengthening method can improve the flexural bearing capacity of concrete beams and reduce the development of deflection and cracks, there is a strong stress hysteresis reaction, which results in a poor reinforcement effect. This is because the performance of the reinforcement members mainly depends on the original number of reinforcements in the concrete beams; thus, the high tensile strength of the FRP sheets is not fully exploited $[56,105,106]$. Moreover, the most effective 
TABLe 5: Mechanical properties of materials [96].

\begin{tabular}{|c|c|c|c|c|c|}
\hline Material & Yield stress (MPa) & Yield strain (\%) & Ultimate strength $(\mathrm{MPa})$ & Rupture strain (\%) & Elastic modulus (GPa) \\
\hline Tensile steel bar & 467 & 0.242 & 628 & - & 193 \\
\hline Compressive steel bar & 467 & 0.242 & 628 & - & 193 \\
\hline Stirrup & 453 & 0.227 & 467 & - & 200 \\
\hline CFRP grid & - & - & 1400 & 1.40 & 100 \\
\hline BFRP grid & - & - & 1760 & 2.20 & 80 \\
\hline
\end{tabular}

way to strengthen the concrete columns with FRP sheets or other laminates is to confirm the shear strength of concrete members according to the deformation constraint of the structure. However, the reinforcement effect depends on the shape of the concrete. Researchers [107-109] reported that the shear strength and deformation capacity of rectangular concrete columns can be improved via bonding with FRP sheets, but there was the upper limit of the compressive capacity. If the rectangular column is treated with a certain radian, the compressive bearing capacity can be significantly improved. Bonding FRP materials has the fatal problem that the strength cannot be fully used, and there is a stress hysteresis reaction. The key to solving this problem is applying prestress to FRP materials. The reinforcement of prestressed FRP sheets can effectively solve the problem of enhancing the time efficiency, which not only reduces the existing load effect of the reinforcement members but also reduces the existing deformation and the widths of cracks in the reinforcement members. After the reinforcement, the prestressed FRP materials and the concrete members are subjected to the force simultaneously, which can prevent deformation, the development of existing cracks, and the generation of new cracks. However, anchors that have excellent performance, are practically applicable, and fully exploit the tensile strength of the FRP sheets are necessary to achieve reliable prestressed FRP reinforcement.

However, the significant disadvantage of reinforced members with FRP laminates is the debonding failure between the FRP and the concrete, which can suppress the strengthening effect for EB FRP laminates [110, 111].

The bonding interface between FRP materials and concrete members is the weak links in the stress process, and the failure modes are brittle failure and debonding failure. Thus, the debonding failure can be divided into four types [112-114]: (1) the stress concentration at the end of the bond interface, resulting in debonding; (2) the shear cracks in the reinforced members, resulting in debonding; (3) the flexural cracks that extend to the reinforced members, resulting in debonding; and (4) the layer debonding along the original reinforcement of the reinforced members.

Furthermore, in the strengthening method called "grooving," the EB reinforcement is applied on/in grooves to prevent debonding failure and enhance the ultimate bearing capacity [56]. Reinforced concrete members prepared using different strengthening methods are shown in Figure 4. For strengthening with one layer of an FRP sheet, the effects of the failure loads and displacements on the EB reinforcement on grooves were similar to those on the EB reinforcement in grooves. For strengthening with two or three layers of FRP sheets, the technique of $\mathrm{EB}$ reinforcement in grooves led to higher failure loads and displacements than EB reinforcement on grooves.

3.3. Strengthening with FRP Grids. FRP grids have longitudinal and transverse fiber bars, and both have a certain strength and stiffness. Fiber bars in both the longitudinal and transverse directions are subjected to tensile forces, which can act as constraints in both directions. The strengthening method for the FRP grid involves fixing the FRP grid on the concrete surface with anchors and then applying a sealing treatment. FRP grids can be used to strengthen the structures in special environments and exhibit good application prospects. FRP grids are always used together with polymer mortar [20, 96]. First, FRP grids are fixed by a mechanical anchorage; then, a layer of polymer mortar is added outside as a protection layer, which can improve the uniformity of the force transmission, as well as the debonding failure resistance, durability, and fire resistance. The installation procedures for the cast-in-place method are presented in Figure 5.

The strengthening technology for FRP grids has the following characteristics [20, 96, 115-117]:

(1) FRP grids are light and thin. They are significantly lighter than steel bars, and the section of the FRP grid is thinner than that of the steel bar. Moreover, the FRP grid is easy to transport and apply without heavy-lifting equipment.

(2) The materials of the FRP grids are composed of highstrength fiber and resin with good corrosion resistance; therefore, the FRP grid has excellent durability in cold areas and coastal areas.

(3) The continuous reinforcing fibers are distributed in two directions. The bond-slip resistance is good, and debonding failure between the reinforcing material and the concrete does not easily occur, owing to the mechanical anchoring and the polymer mortar. When FRP grid is used in the bending reinforcement, it can not only improve the bearing capacity but also enhance the stiffness and cracking resistance of the reinforced member.

(4) With the protection of polymer mortar, the FRP grid improves the impact resistance, fire resistance, and durability. Therefore, FRP grids can be used to replace steel bars in some new buildings with special requirements for anticorrosion, antimagnetic, antiseismic, and antiexplosion materials. 


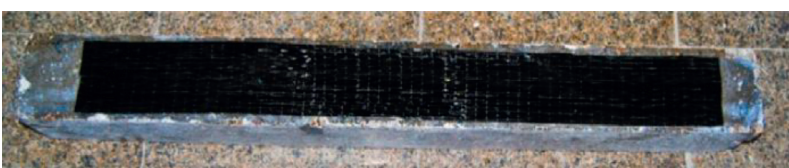

(a)

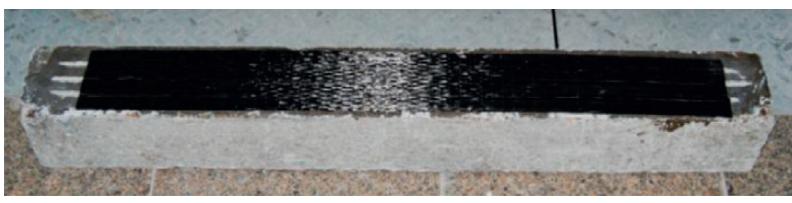

(b)

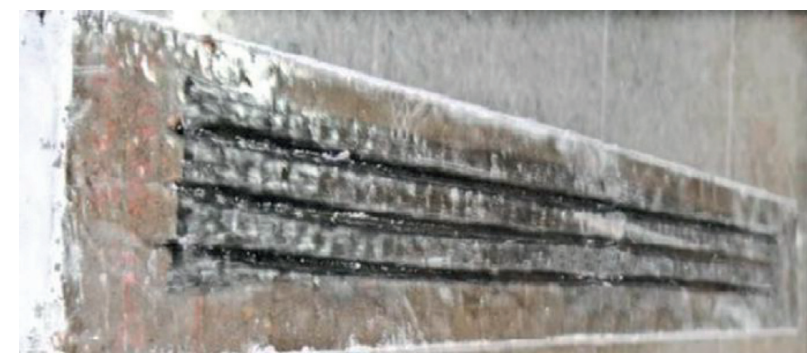

(c)

FIGURE 4: Specimens strengthened with (a) conventional surface preparation method, (b) externally bonded reinforcement on grooves technique, and (c) externally bonded reinforcement in grooves technique [56].

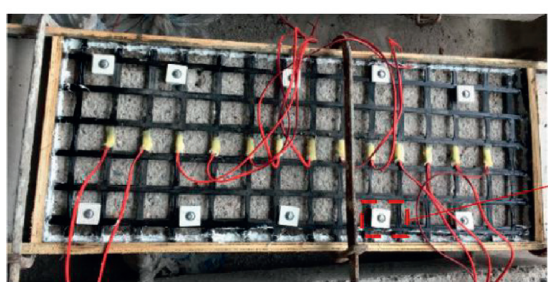

(a)
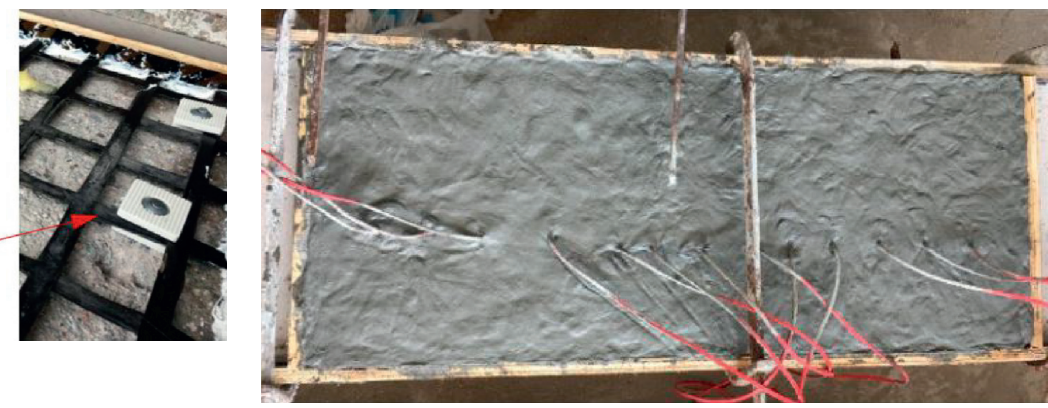

(b)

FIGURE 5: Installation procedures for the cast-in-place method [96].

Additionally, in comparison with the reinforcement method of FRP sheets, FRP grids can improve the stiffness of the members and be less prone to debonding failure; thus, they are more suitable for reinforcement in harsh environments. Because FRP sheets are soft and their adhesion relies on the resin, there are limitations in reinforcing the concrete structures. When the interface roughness of the reinforced structure is inadequate, the properties are significantly degraded. Furthermore, FRP sheets cannot be applied in humid environments or underwater. Therefore, the overall strengthening effect of FRP grids is better than that of FRP sheets.

The Niiborigawa Bridge in Japan had long suffered erosion due to salt and is a representative example of the removal of the deteriorating concrete and the use of CFRP grids and polymer mortar for strengthening [118]. During the eight-year natural aging process, the CFRP grids in the concrete beam maintained excellent properties, including the strength, stiffness, and corrosion resistance. Zhang et al. [48] performed static and cyclic loading tests of three oneway concrete slabs strengthened by CFRP grids and steel bars. They found that the reinforcement ratio significantly affected the flexural stiffness because the stiffness of the concrete slab strengthened by CFRP grids decreased significantly after the crack initiation in comparison with that of the concrete slab strengthened by steel bars. Brunton et al. [119] studied the punching shear capacity of a full-scale concrete bridge deck strengthened by pultruded FRP grids and found that the Jacobson equation could predict the punching shear capacity of concrete decks with or without edge restraint. EB grids are effective for enhancing the bearing capacities and deformation capacities of concrete members. Moreover, the effects of the number of FRP grid layers, type of FRP grids (CFRP, GFRP, or BFRP), type of bonding agent (inorganic material or epoxy resin), and compressive stress level on the mechanical performance of reinforced members are major parameters [120]. Under sufficient anchoring, the flexural capacities and deformabilities of members strengthened by FRP grids increased by factors of $>4$ and $>1.3$, respectively. Strengthening concrete bridge decks with FRP grids solves the problems of fatigue and corrosion; additionally, the ultimate load is higher than that in the case of strengthening with steel grids [121-123]. Moreover, fiber-reinforced concrete can solve the problem 
of brittle failure of concrete plates reinforced with FRP grids. Yang et al. [96] investigated the effects of the ratio of the shear span to the effective depth, matrix type, FRP grid type, and installation method on the shear capacity of the strengthened beam. They found that the reinforcement with FRP grids enhanced the shear capacity of the reinforced beam, particularly with the application of the prefabrication method. Additionally, they reported that, in comparison with CFRP grids and the cast-in-place method, the beams strengthened with BFRP grids in the prefabrication method were more suitable for the reinforced beam.

3.4. Strengthening with Prestressing FRP Bars. In the external prestressed structure, the prestressed bars are arranged outside the section, and the prestress is applied to the structure only by the anchorage area and steering block. The system comprises an externally prestressed pipe, paste (anticorrosive grease or cement), an anchorage system, and a steering block [124-127]. External prestressing reinforcement technology can improve the internal force and deformation of the control section and enhance the bearing capacity, cracking resistance, and deformation resistance of the bridge because the internal force generated by prestressing on the structure offsets parts of the internal force generated by the loads.

The external prestressing technique is particularly suitable for the reinforcement of the concrete bridge in the following situations:

(1) The bearing capacity of the structures decreases owing to the corrosion of steel.

(2) The load grade of the bridge must be improved.

(3) The cracking of the beam and the fatigue stress of the reinforcement should be controlled in a reasonable range.

The external prestress on the strengthening of the bridge can result in the distribution of the stress, which can enhance the performance of the structure under normal service loads. Additionally, it is suitable for strengthening various bridges because the arrangement of the external prestressed tendons is flexible. The external prestressing technique has broad application prospects in bridge reinforcement. The external prestressing method is one of the important aspects of the posttensioned prestressing system and has the following advantages for reinforcement.

(1) It is convenient to check, repair, and replace the external prestressed tendons

(2) The arrangement of the prestressed tendons is simple, which simplifies the operation of the posttensioning method

(3) The prestressing tendons have no contact with the concrete member except at the anchorage area and steering block, which reduces the friction loss

(4) It can improve the flexural and shear bearing capacity
(5) The stress generated by the load is distributed uniformly along the length direction with small variation range, which is beneficial to the bearing capacity and fatigue load

The first prestressed concrete bridge using CFRP bars in the world was built in Japan in 1993. Japan was a pioneering country in the use of prestressed FRP bars. CFRP bars were used as suspension cables to build concrete bridges in Switzerland, Denmark, the United Kingdom, and Canada [128-130]. The external prestressing technology of CFRP bars can be applied to new bridge structures, reinforcement, and maintenance operations of bridges owing to the excellent corrosion resistance. Horvatits and Kollegger [131] successfully strengthened a highway concrete bridge with a new external prestressed CFRP system. Nordin and Täljsten [132] strengthened and rehabilitated existing concrete structures with CFRP tendons. Their objective was to evaluate the bearing capacity and service life of existing railway bridges when the existing load capacity increased by $25 \%$ and the train speed increased to $350 \mathrm{~km} / \mathrm{h}$. However, the desired effect was not achieved, owing to the anchorage. Matta et al. [133] controlled the vertical deflection of a bridge with a reinforcement of external posttensioned CFRP tendons (the CFRP bar with a diameter of $12.7 \mathrm{~mm}$ was arranged under the beam). Macdougall et al. [134] successfully replaced corroded posttensioned unbonded prestressed steel tendons with CFRP tendons via the posttensioned method in a parking garage in Toronto. El-Hacha and Elbadry [24] investigated the effects of the span-to-depth ratio, partial prestressing ratio, and reinforcing index on 12 concrete beams with strengthening external prestressed CFRP tendons. They reported that the flexural capacity of the strengthened beam was $70 \%$ higher than that of the unreinforced beam. Moreover, they obtained the formula for the stress increment of the CFRP tendons according to the deformation.

At present, the anchorage methods for external prestressing tendons mainly include broadening the cross section of the beam end, adding a concrete tooth plate, and steel plate anchorage. The former two methods are mostly applied to newly built structures, and the latter method is the most common technique for external prestressed reinforcement owing to its advantages of light weight and convenient construction.

3.5. Near-Surface Mounted FRP. NSM FRP is an improved version of the traditional EB FRP method [37]. NSM FRP reinforcement involves placing FRP bars or laminates into precut grooves on the surface of the concrete members with the corresponding binder. The procedure of NSM FRP reinforcement is as follows: (1) forming the grooves; (2) cleaning the grooves; (3) half-filling the grooves with the filling material, followed by insertion of the FRP bars; and (4) filling the groove with the filling material to the surface level, as shown in Figure 6.

In comparison with the traditional EB FRP method, the NSM FRP method can significantly improve the efficiency 

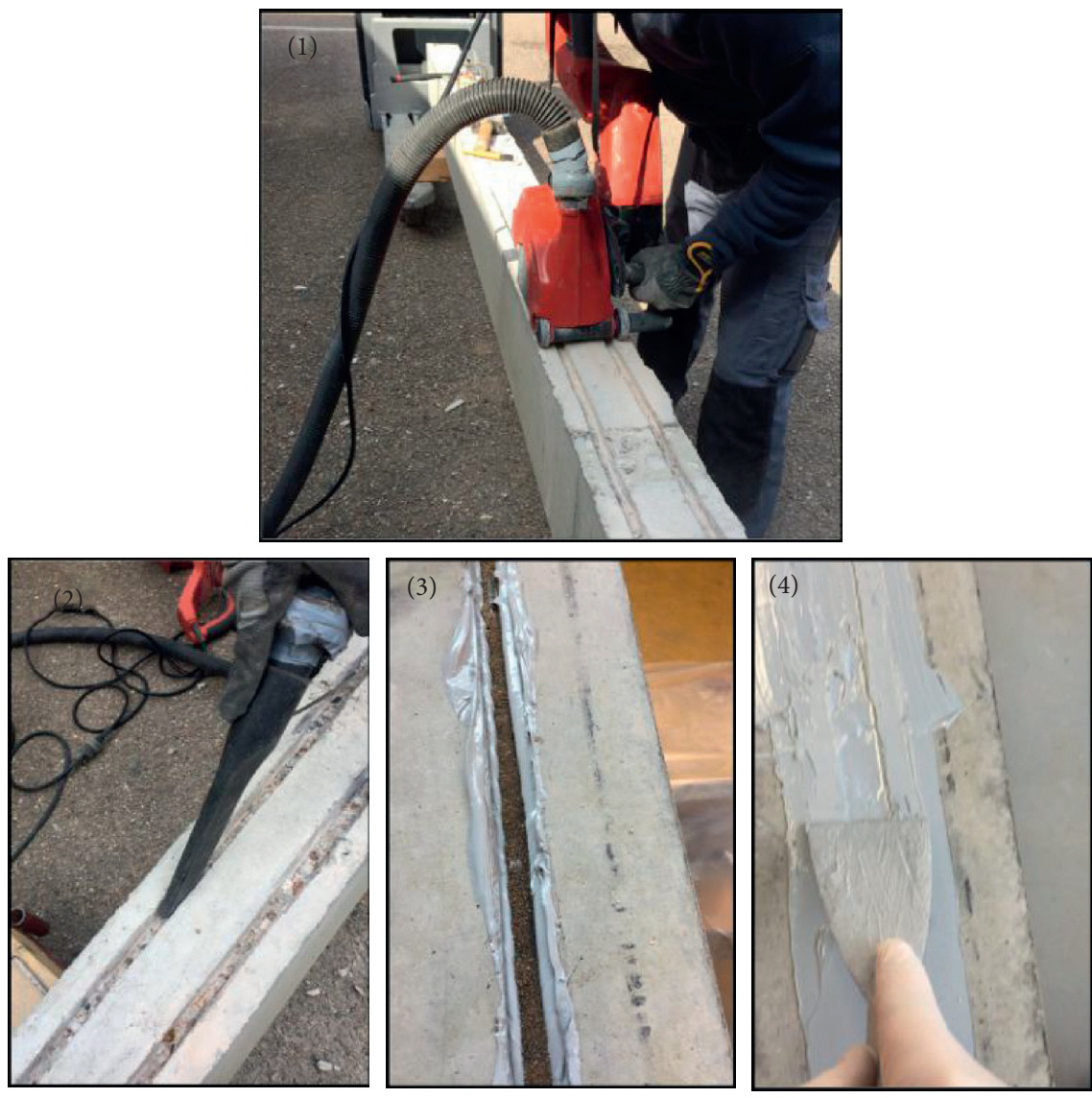

FIGURE 6: The procedure of NSM FRP [37].

and utilization ratio $[135,136]$; additionally, it has significant advantages for the practical applications of strengthening bridge structures:

(1) NSM FRP enhances the bonding performance between the FRP materials and concrete and is less prone than EB FRP to debonding failure

(2) NSM FRP increases the bonding area between the FRP materials and concrete, improving the punching shearing capacity of the bridge structure $[137,138]$

(3) Improving the bonding performance between the FRP and concrete can increase the utilization rate of FRP materials and the ductility of the bridge structure

(4) FRP bars can be easily anchored on the adjacent components [137]

In 1949, Asplund [139] strengthened a bridge by forming grooves on the surface of the members; however, bonding failure easily occurred owing to the use of cement paste as the binder and steel bars as the reinforcement materials, which hindered the further development of this technology. With the development of new binders and the application of FRP materials in the construction, the NSM FRP technique has attracted the attention of researchers. Casadei et al. [140] repaired a damaged concrete bridge with several soffit slab longitudinal cracks using EB FRP laminates and NSM FRP bars, as shown in Figures 7 and 8. Static load tests and finiteelement analysis revealed that both reinforcement techniques were effective for strengthening the concrete bridge. Alkhrdaji et al. [141] performed the same reinforcement tests on a decommissioned and to-be-demolished bridge. They reported that both EB FRP sheets and NSM FRP rods reduced the deflections and increased the ultimate load capacity; even the latter had a higher capacity and better bonding performance. Moreover, the different reinforcement methods led to different failure modes. When the bridge deck was strengthened with EB FRP sheets, the failure mode was the rupture and peeling of FRP sheets; when the bridge deck was reinforced with NSM FRP rods, the rupture of FRP rods was the main failure mode.

The bonding performance between the FRP and concrete significantly affects the strengthening effect of NSM FRP bars. Many researchers [135, 136, 142, 143] have investigated the bonding performance between FRP and concrete via different test methods (mainly the direct pull-out method and the bending beam method). Among the various test methods, the direct pull-out method has a direct force transmission path and is easy to operate owing to the small volume of the specimens, but the requirement of the specimen molding is very strict because slightly eccentric loading significantly affects the results. The bending beam method can solve the problem of vertical adjustment of the loading, but the specimen volume is large, the force 


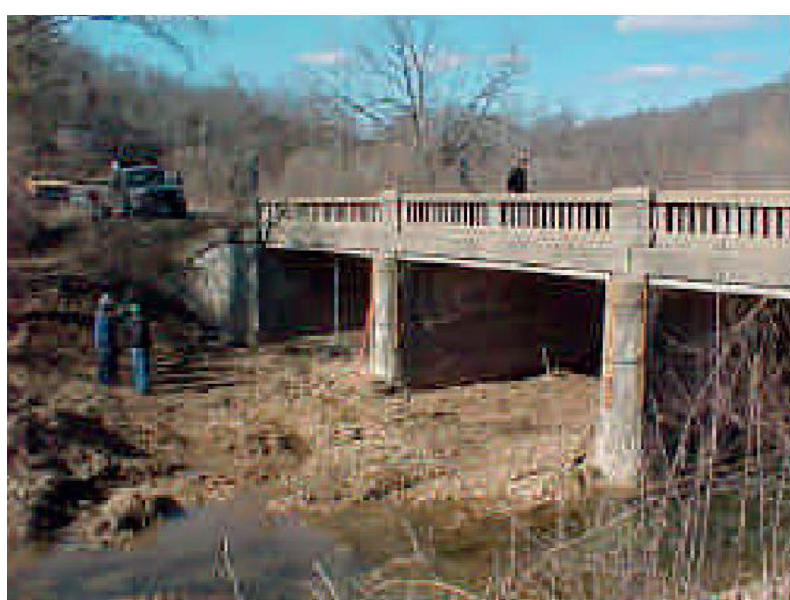

(a)

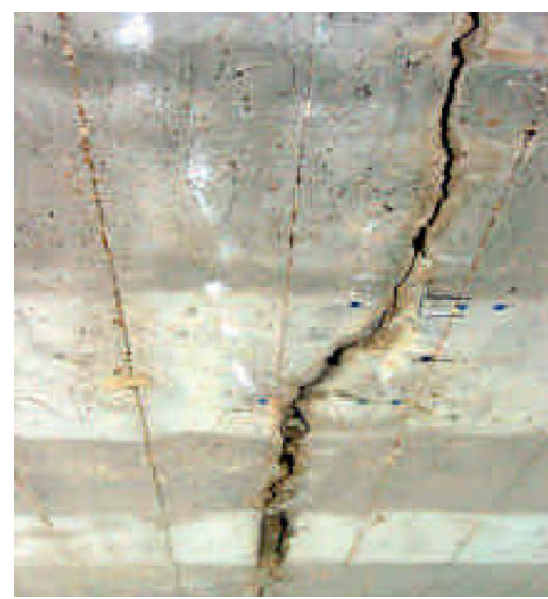

(b)

Figure 7: Martin Spring Bridge (a) and its soffit slab longitudinal crack (b) [140].

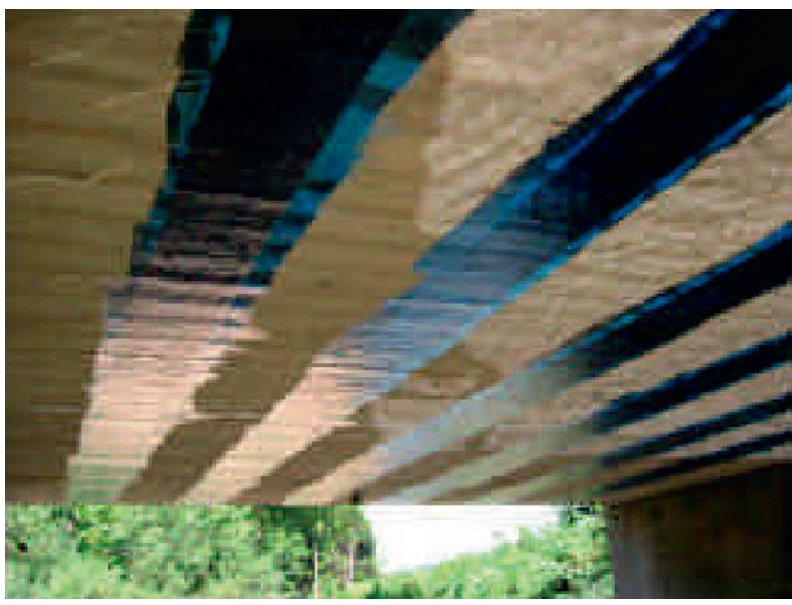

(a)

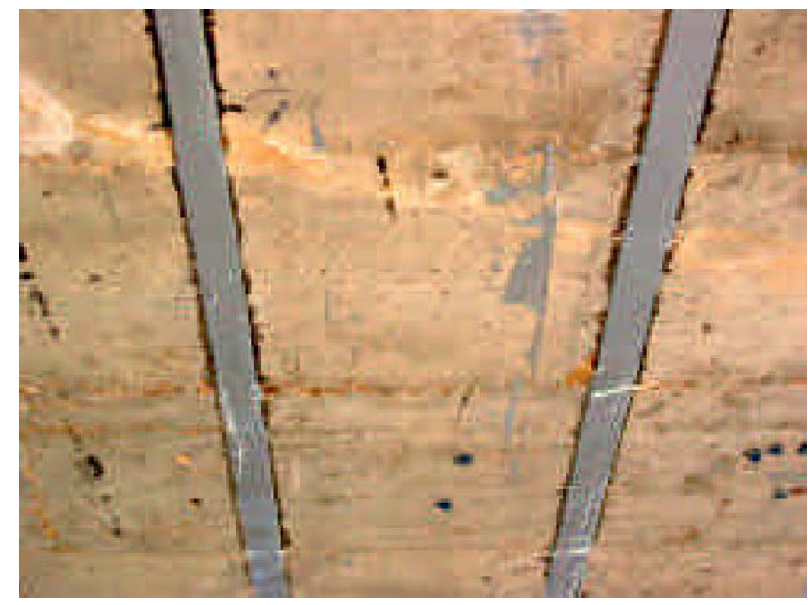

(b)

Figure 8: Externally bonded FRP laminates (a) and NSM FRP bars (b) [140].

transmission is complex, and displacement control loading cannot be used. Additionally, many factors affect the bonding performance between the FRP and concrete, including the concrete strength, the depth and spacing of the grooves on the surface of the concrete members, the bond length of the FRP, the types of binders, and the environmental conditions.

In addition to the bonding performance, the flexural and shear properties of concrete structures reinforced with NSM FRP bars have been investigated by many researchers worldwide [21, 144-149]. NSM FRP can significantly improve the flexural performance of reinforced concrete members, and the failure modes of flexural reinforcement mainly include concrete failure in the compression zone, FRP fracture, debonding failure between the concrete and the end of the FRP, and debonding failure caused by the main crack at the midspan. Zhang and Teng [150] developed a bond-slip relationship model that accurately simulated the debonding failure between the concrete and the end of the FRP; the model was verified using experimental results.

Michael et al. [151] conducted an experimental program on a unidirectional concrete slab for the deck analysis model. They found that the effect of the resin binder on the enhancement of the bearing capacity was stronger than that of cement as a binder, and steel bars as embedded reinforcement was better for constraint member cracking than FRP bars. Similar studies were performed by Hosseini et al. [152], who applied different prestress levels to NSM CFRP laminates in reinforced concrete slabs. The experimental results indicated that the bearing capacity at the serviceability and ultimate limit states increased significantly as the prestress increased. The effects of the FRP type, cross-sectional shape, surface treatment method, and prestress level on the flexural performance of bridge decks strengthened with NSM FRP in the negative-bending moment regions were investigated [153]. The results indicated that the NSM FRP method was 
beneficial for increasing the yield strength and ultimate strength of the reinforced concrete slab. Martin et al. [143] reported that compressive membrane action can enhance the bearing capacity of concrete slabs strengthened with NSM FRP. Therefore, it is necessary to consider the effects of the panel boundary support conditions on the flexural performance of bridge decks strengthened with NSM FRP. Regarding the theoretical model analysis of the strength of concrete bridge decks strengthened with NSM FRP, calculation methods for the flexural and shear capacity should be established considering the compressive membrane action [153].

\section{Properties of the Reinforced Members}

4.1. Flexural Performance. Bridge elements may be continuously subjected to bending action; thus, the flexural strength of the structural members must be enhanced. Different reinforcement methods can result in different degrees of enhancement of the flexural performance of the strengthened members. The common reinforced methods are EB FRP laminates, externally prestressed FRP tendons, and NSM FRP bars [23, 27, 148, 154-159].

Compared with unreinforced members, the loading capacity of the concrete beams strengthened with FRP CFRP sheets was higher, but the ductility was lower [112], and the main failure mode was peeling failure of the concrete cover near the FRP sheets. Choobbor et al. [155] applied CFRP/ BFRP composite sheets to nine reinforced concrete beams and investigated the flexural performance of the beams. They found that the ultimate capacity of the reinforced members increased by $66 \%-75 \%$ compared with that of the unreinforced beam. Moreover, they established a precise finiteelement model for predicting the ultimate load-carrying capacity and the deflections (the deviation was $<12 \%$ ). Additionally, researchers have studied new FRP reinforcement materials and found that the bearing capacity of members strengthened with the new FRP (natural FRP) was enhanced by $41 \%$ (larger than the enhancement for strengthening with CFRP) [160]. The strengthening effect of FRP plates on the reinforcement of concrete structures is better than that of FRP sheets owing to the large crosssectional areas, the high stiffness, and the convenience of the construction [11]. The effect of the thickness of FRP plates on the flexural performance of a concrete beam strengthened with the FRP plates was investigated [161]. Compared with an unreinforced beam, thicker FRP plates resulted in a higher ultimate load; the largest increment was $112.2 \%$. Although the tensile strength and elastic modulus of FRP plates are lower than those of steel plates, the increase in the ultimate lateral load-carrying capacity of the members with EB FRP plates is approximately equal to that for members with EB steel plates.

Together with the results of the reinforcement experiment, the researchers provided a calculation method for the cracking moment, crack width, and deflection of reinforced members with prestressed CFRP plates [11]. The crack moment and ultimate moment increased by $121 \%$ and $103 \%$, respectively, for reinforced slabs strengthened with external prestressed FRP tendons [162]. In the external prestressing system, the anchoring technology was the key for strengthening the one-way concrete slab with externally prestressed tendons. An innovative, reliable, and efficient anchoring technology ensured the prestressing level and recovered the long-term prestressing losses. To enhance the bonding performance between the FRP materials and the concrete, the NSM FRP method was introduced. Compared with other types of FRP, CFRP was considered to be the most suitable for the NSM FRP strengthening technique owing to its high stiffness and strength. The dosage of FRP materials, the steel reinforcement ratio, and the failure modes are the key parameters for the effectiveness of the strengthening $[163,164]$. Moreover, because the ratio of the perimeter to the cross-sectional area was higher for FRP strips than for FRP round bars, the bond efficiency of the NSM FRP strips was better than that of the NSM FRP round bars for the strengthening of concrete members via the NSM FRP technique [163]. Many researchers have investigated the flexural performance of the concrete structures (beams or slabs) strengthened with NSM FRP materials (laminates, bars, and strips) $[26,146-148,165]$. They found that the NSM FRP technique can enhance the load-carrying capacity of the strengthened members and maintain a corresponding level of moment redistribution. However, the NSM CFRP strip method enhanced the flexural stiffness of the strengthened concrete beam after the cracking stage instead of at the stage of elasticity [148].

4.2. Bonding Performance. Concrete members reinforced with FRP sheets or plates are attracting increasing attention from engineers and researchers for construction applications owing to their excellent advantages, e.g., their corrosion resistance and light weight. There are numerous bond-strength models for EB FRP sheet applications [113, 114, 166-171]. Bonding is the key for the stress transfer between the FRP materials and the concrete substrate [172]. Many design criteria limit the strain of the FRP sheets to prevent midspan debonding failure, and the interaction of the concrete protective layer, FRP sheets, and steel bars results in midspan debonding failure [173]. The effects of the concrete strength, the quality of the concrete surface, the thickness of the glue line, and the characteristics of FRP sheets (types, stiffness, bond length, width, and bond layers) on the bond strength of concrete members strengthened with FRP materials have been investigated [174-177]. Although the FRP sheets covered the entire tension area of the reinforced member, they did not prevent debonding failure [112].

With the advancement of FRP applications, researchers $[178,179]$ have developed techniques for preventing debonding failure using steel bolting and bonded FRP U-shaped channels or jackets at the end of the beam or at intermediate locations. However, the bolting method can damage the FRP materials during the fabrication process [172]. One of the main weaknesses of the EB FRP laminate method is the premature debonding of the FRP materials, which results in the low utilization of the materials [38]. Researchers demonstrated that the method of EB 
reinforcement on grooves can successfully postpone the debonding in applications of flat slabs. Ceci et al. [180] studied the debonding failure mechanism of a concrete beam strengthened with FRP sheets and predicted the debonding failure mode.

The ultimate bond strength was determined using the model of Chen and Teng, as follows:

$$
\begin{aligned}
P_{C \text { and } T} & =0.427 \beta_{p} \beta_{1} \sqrt{f_{c}} b_{f} L_{e}, \\
\beta_{p} & =\sqrt{\frac{\left(2-b_{f}\right) / b_{c}}{\left(1+b_{f}\right) / b_{c}}}, \\
L_{e} & =\sqrt{\frac{E_{f} t_{f}}{\sqrt{f_{c}}},} \\
\beta_{1} & = \begin{cases}1, & L \geq L_{e}, \\
\sin \frac{\pi L}{2 L_{e}}, & L<L_{e},\end{cases}
\end{aligned}
$$

where $f_{c}$ represents the compressive strength of the concrete, $b_{f}$ represents the width of the FRP sheets, $L_{e}$ represents the effective bond length, $b_{c}$ represents the width of the reinforced structure, $E_{f}$ represents the elastic modulus of the FRP sheets, and $t_{f}$ represents the thickness of the FRP sheets.

To adopt the method of EB reinforcement on grooves, a coefficient considering the effect of grooving was added to the model of Chen and Teng, as follows:

$$
\begin{aligned}
P_{\text {EBROG }} & =\beta_{g} P_{C \text { and } T}, \\
\beta_{g} & =f_{c}^{-0.33}\left(E_{f} t_{f}\right)^{-0.88}\left(8.1-0.006 h_{g}^{2}+0.1 h_{g}+0.04 b_{g}\right),
\end{aligned}
$$

where $h_{g}$ represents the height of the grooves and $b_{g}$ represents the width of the grooves.

4.3. Ductility. The ductility is a necessary factor for evaluating the ability of the members to withstand plastic deformation before ultimate failure. The evaluation method for the ductility involves calculating the ductility coefficient, which can be represented by different physical quantities, and its concept and calculation method are not unique. The traditional ductility coefficients include the displacement ductility coefficient, angular ductility coefficient, curvature ductility coefficient, and energy ductility coefficient.

At present, the limit state design method requires us to not only ensure the bearing capacity of the structure but also give the structure ductility. On one hand, a structure with good ductility can absorb a large amount of power before failing. On the other hand, there are obvious deformation signs before the damage, which can prevent sudden damage caused by an overload. The FRP material plays its role after the yielding of steel bar, and its ultimate tensile strain is smaller than that of the steel bar.
Additionally, the stress-strain relationship is linear; thus, the ductility of concrete members reinforced with FRP is lower than that of the members without reinforcement. To qualitatively describe and measure the reduction of the ductility after reinforcement, three different ductility coefficients are used for analyzing the ductility performance of reinforced concrete bridge decks after reinforcement on the basis of the failure modes and loaddeflection curves. The displacement coefficient is the ratio of the ultimate deformation to the yield deformation, which is based on the load-deflection relationship [181], as indicated by

$$
\lambda_{\Delta}=\frac{\Delta u}{\Delta y}
$$

where $\lambda_{\Delta}$ is the displacement coefficient, $\Delta u$ represents the deflection of the midspan of the beam corresponding to the ultimate load, and $\Delta y$ represents the deflection corresponding to the yield load. Reinforced beams strengthened with NSM FRP bars exhibited lower ductility than the unreinforced members. The displacement coefficients of the reinforced beams were reduced by $31.3 \%-66.7 \%$ [37].

The energy ductility coefficient is calculated using the amount of deformation energy absorbed, according to the load-deflection curve or load-curvature curve. The energy ductility coefficient is given as follows:

$$
\lambda_{w}=\frac{W_{u}}{W_{y}},
$$

where $\lambda_{w}$ is the energy ductility coefficient. $W_{u}$ and $W_{y}$ represent the deformation energy values of the members corresponding to the ultimate load and yield load, respectively, and they are determined by calculating the area enclosed by the measured load-deflection or load-curvature curve and the $\mathrm{X}$-axis.

The energy ductility coefficient describes the ability of the member to absorb energy after yielding, and the displacement ductility coefficient is calculated based on the deflection value of a single point. With the advancement of research, scholars have realized the limitation of the traditional ductility coefficient and proposed a comprehensive ductility coefficient considering the bearing capacity and deformation [182]. The comprehensive ductility coefficient is determined as follows:

$$
J=S_{J} D_{J}=\frac{M_{u}}{M_{c}} \frac{\varnothing_{u}}{\varnothing_{c}}
$$

where $J$ is the comprehensive ductility coefficient, $S_{J}=\left(M_{u} / M_{c}\right)$ is the bearing capacity factor, $D_{J}=\left(\varnothing_{u} / \varnothing_{c}\right)$ is the deformation coefficient, $M_{u}$ represents the ultimate bending moment, $\varnothing_{u}$ represents the ultimate curvature, and $M_{c}$ and $\varnothing_{c}$ represent the bending moment and curvature when the compressive strain of the concrete at the bottom of the beam is 0.001 , respectively. The comprehensive ductility coefficient, which depends on the bearing capacity factor and deformation coefficient, is more comprehensive in the safety reserve of structures or components. 


\section{Conclusions}

Although FRP materials cannot replace traditional steel and concrete materials over large areas, they are expected to become necessary complements to the traditional structural materials. The use of FRP materials enables challenging engineering problems to be easily solved, presents new development opportunities in civil engineering, and yields significant economic benefits. The objectives of this study were to enhance researchers' understanding of the strengthening methods for bridge structures and to improve the reinforcement techniques for civil engineering and building construction.

This paper discussed the development and application of FRP materials and the strengthening techniques for bridge structures. Bridge structures bear traffic loads directly. The load distribution is highly irregular, and the failure law is more complex than those for other structures. For strengthening, compared with traditional steel, FRP materials exhibit better application prospects in the field of reinforcement, owing to their light weight, high strength, and corrosion resistance. EB FRP laminates are widely used for strengthening; however, NSM FRP bars have more significant advantages and have been the subject of numerous studies. Moreover, research on the bonding problem of reinforcement technology has been conducted for many years. The application of anchorage measures improves the cooperative working performance between the FRP materials and concrete, which alleviates this problem to a certain extent.

The bridge decks and beams are usually considered as strips to study the bending performance; however, in practice, the bridge deck is restrained by the supporting beam and produces compressive membrane action. It is necessary to consider the effects of boundary support conditions on the flexural reinforcement performance of the bridge deck. A calculation formula for the bearing capacity of the bridge deck after strengthening, considering the effect of the compressive membrane action, should be established. Moreover, the bridge deck usually bears a local area load/tire load; thus, it is necessary to analyze the mechanical performance and failure mechanism of the reinforced bridge deck under the local loads.

The bridge decks and beams are important components of bridge structures. Reasonable and effective strengthening methods have been proposed for repairing damaged bridges and improving the bearing capacity of existing bridges, which can extend the service life of old bridge structures for traffic and transportation and yield significant economic benefits.

\section{Conflicts of Interest}

The authors declare that there are no conflicts of interest regarding the publication of this paper.

\section{Authors' Contributions}

Hu W.L. conceptualized this study; Hu W.L. was responsible for the methodology; investigation was conducted by $\mathrm{Hu}$
W.L. and Yuan H.Y.; data curation was performed by Yuan H.Y.; Hu W.L. prepared the original draft; Li Y. performed review and editing; visualization was performed by Yuan H.Y.; and Li Y. supervised the study. All authors have read and agreed to the published version of the manuscript.

\section{Acknowledgments}

The authors disclosed receipt of the following financial support for the research, authorship, and/or publication of this article: this work was financially supported by the Natural Science Basic Research Program of Shannxi (Program No. 2020JQ-377).

\section{References}

[1] A. Costa and J. Appleton, "Case studies of concrete deterioration in a marine environment in Portugal," Cement and Concrete Composites, vol. 24, no. 1, pp. 169-179, 2002.

[2] M. A. Pech-Canul and P. Castro, "Corrosion measurements of steel reinforcement in concrete exposed to a tropical marine atmosphere," Cement and Concrete Research, vol. 32, no. 3, pp. 491-498, 2002.

[3] X. Shi, N. Xie, K. Fortune, and J. Gong, "Durability of steel reinforced concrete in chloride environments: an overview," Construction and Building Materials, vol. 30, pp. 125-138, 2012.

[4] M. Safehian and A. A. Ramezanianpour, "Assessment of service life models for determination of chloride penetration into silica fume concrete in the severe marine environmental condition," Construction and Building Materials, vol. 48, pp. 287-294, 2013.

[5] B. Ji, R. Liu, C. Chen, H. Maeno, and X. Chen, "Evaluation on root-deck fatigue of orthotropic steel bridge deck," Journal of Constructional Steel Research, vol. 90, no. nov, pp. 174-183, 2013.

[6] B.-J. Han, S.-I. Yoon, B.-J. Choi, J.-W. Choi, and S.-K. Park, "Analysis study on fatigue stress on the orthotropic steel deck applied polymer concrete pavement," Journal of the Korea Institute for Structural Maintenance and Inspection, vol. 18, no. 5, pp. 68-77, 2014.

[7] H. Fang, F. Zou, W. Liu, C. Wu, Y. Bai, and D. Hui, "Mechanical performance of concrete pavement reinforced by CFRP grids for bridge deck applications," Composites Part B: Engineering, vol. 110, pp. 315-335, 2017.

[8] M. Onofrei, Durability of GFRP Reinforced Concrete in Field Structures, American Concrete Institute, Indiana, IN, USA, 2005.

[9] M. A. Erki and S. H. Rizkalla, "FRP reinforcement for concrete structures," Concrete International, vol. 15, pp. 48-53, 1993.

[10] R. A. Hawileh, H. A. Rasheed, J. A. Abdalla, and A. K. AlTamimi, "Behavior of reinforced concrete beams strengthened with externally bonded hybrid fiber reinforced polymer systems," Materials \& Design, vol. 53, pp. 972-982, 2014.

[11] W. Xue, Y. Tan, and L. Zeng, "Flexural response predictions of reinforced concrete beams strengthened with prestressed CFRP plates," Composite Structures, vol. 92, no. 3, pp. 612-622, 2010.

[12] J. Sim and H. Oh, "Structural behavior of strengthened bridge deck specimens under fatigue loading," Engineering Structures, vol. 26, no. 14, pp. 2219-2230, 2004. 
[13] A. El-Ragaby, E. El-Salakawy, and B. Benmokrane, "Fatigue analysis of concrete bridge deck slabs reinforced with E-glass/vinyl ester FRP reinforcing bars," Composites Part B: Engineering, vol. 38, no. 5-6, pp. 703-711, 2007.

[14] H. Toutanji and Y. Deng, "Strength and durability performance of concrete axially loaded members confined with AFRP composite sheets," Composites Part B: Engineering, vol. 33, no. 4, pp. 255-261, 2002.

[15] B. Benmokrane, B. Zhang, and A. Chennouf, "Tensile properties and pullout behaviour of AFRP and CFRP rods for grouted anchor applications," Construction and Building Materials, vol. 14, no. 3, pp. 157-170, 2000.

[16] S. El-Gamal and O. AlShareedah, "Behavior of axially loaded low strength concrete columns reinforced with GFRP bars and spirals," Engineering Structures, vol. 216, p. 110732, 2020.

[17] P. Zhang, Y. Hu, Y. Pang et al., "Influence factors analysis of the interfacial bond behavior between GFRP plates, concrete," Structures, vol. 26, pp. 79-91, 2020.

[18] P. Feng, Development and Study on an Innovative FRP Bridge Deck, Tsinghua University, Beijing, China, 2004.

[19] R. Realfonzo, E. Martinelli, A. Napoli, and B. Nunziata, "Experimental investigation of the mechanical connection between FRP laminates and concrete," Composites Part B: Engineering, vol. 45, no. 1, pp. 341-355, 2013.

[20] W. He, X. Wang, and Z. Wu, "Flexural behavior of RC beams strengthened with prestressed and non-prestressed BFRP grids," Composite Structures, vol. 246, p. 112381, 2020.

[21] M. Jalali, M. K. Sharbatdar, J.-F. Chen, and F. Jandaghi Alaee, "Shear strengthening of RC beams using innovative manually made NSM FRP bars," Construction and Building Materials, vol. 36, pp. 990-1000, 2012.

[22] H.-T. Wang and G. Wu, "Crack propagation prediction of double-edged cracked steel beams strengthened with FRP plates," Thin-Walled Structures, vol. 127, pp. 459-468, 2018.

[23] A. M. Sayed, X. Wang, and Z. Wu, "Finite element modeling of the shear capacity of RC beams strengthened with FRP sheets by considering different failure modes," Construction and Building Materials, vol. 59, pp. 169-179, 2014.

[24] R. El-Hacha and M. Elbadry, "Strengthening concrete beams with externally prestressed carbon fiber composite cables," in Proceedings of the International Conference on Fiber Reinforced Polymers for Reinforced Concrete Structures, Cambridge, UK, July 2001.

[25] H. Oh and J. Sim, "Punching shear strength of strengthened deck panels with externally bonded plates," Composites Part B: Engineering, vol. 35, no. 4, pp. 313-321, 2004.

[26] Y. Yang, M. F. M. Fahmy, J. Cui, Z. Pan, and J. Shi, "Nonlinear behavior analysis of flexural strengthening of RC beams with NSM FRP laminates," Structures, vol. 20, pp. 374-384, 2019.

[27] R. A. Hawileh, H. A. Musto, J. A. Abdalla, and M. Z. Naser, "Finite element modeling of reinforced concrete beams externally strengthened in flexure with side-bonded FRP laminates," Composites Part B: Engineering, vol. 173, p. 106952, 2019.

[28] K. Khorramian and P. Sadeghian, "Performance of highmodulus near-surface-mounted FRP laminates for strengthening of concrete columns," Composites Part B: Engineering, vol. 164, pp. 90-102, 2019.

[29] R. A. Hawileh, W. Nawaz, J. A. Abdalla, and E. I. Saqan, "Effect of flexural CFRP sheets on shear resistance of reinforced concrete beams," Composite Structures, vol. 122, pp. 468-476, 2015.
[30] R. Thamrin and H. S. Zaidir, "Shear capacity of reinforced concrete beams strengthened with web side bonded CFRP sheets," in International Conference on Sustainable Civil Engineering Structures and Construction Materials: Cedex A, A. Awaludin, T. Matsumoto, S. Pessiki et al., Eds., EDP Sciences, Les Ulis, France, 2019.

[31] R. Thamrin, S. Haris, and Zaidir, "Shear strengthening of reinforced concrete beams with near surface mounted steel bars," in International Conference on Advances in Civil and Environmental Engineering: Cedex A, M. Olivia, A. Marto, K. Yamamoto et al., Eds., EDP Sciences, Les Ulis, France, 2019.

[32] E. I. Saqan, H. A. Rasheed, and T. Alkhrdaji, "Evaluation of the seismic performance of reinforced concrete frames strengthened with CFRP fabric and NSM bars," Composite Structures, vol. 184, pp. 839-847, 2018.

[33] R. A. Hawileh, W. Nawaz, J. A. Abdalla, and E. I. Saqan, External Strengthening of Shear Deficient Reinforced Concrete Beams with Flexural CFRP Laminates, Destech Publications, Inc., Lancaster, PA, USA, 2015.

[34] H. H. Mhanna, R. A. Hawileh, and J. A. Abdalla, "Shear strengthening of reinforced concrete beams using CFRP wraps," in 3rd International Conference on Structural Integrity, P. Moreira and P. J. S. Tavares, Eds., pp. 214-221, Elsevier Science, Amsterdam, Netherlands, 2019.

[35] A. S. D. Salama, R. A. Hawileh, and J. A. Abdalla, "Performance of externally strengthened RC beams with sidebonded CFRP sheets," Composite Structures, vol. 212, pp. 281-290, 2019.

[36] M. T. Junaid, A. Elbana, and S. Altoubat, "Flexural response of geopolymer and fiber reinforced geopolymer concrete beams reinforced with GFRP bars and strengthened using CFRP sheets," Structures, vol. 24, pp. 666-677, 2020.

[37] M. Abdallah, F. Al Mahmoud, A. Khelil, J. Mercier, and B. Almassri, "Assessment of the flexural behavior of continuous RC beams strengthened with NSM-FRP bars, experimental and analytical study," Composite Structures, vol. 242, p. 112127, 2020.

[38] A. Torabian, B. Isufi, D. Mostofinejad, and A. Pinho Ramos, "Flexural strengthening of flat slabs with FRP composites using EBR and EBROG methods," Engineering Structures, vol. 211, p. 110483, 2020.

[39] M. Tahir, Z. Wang, K. M. Ali, and H. F. Isleem, "Shear behavior of concrete beams reinforced with CFRP sheet strip stirrups using wet-layup technique," Structures, vol. 22, pp. 43-52, 2019.

[40] M. Kazemi, J. Li, S. Lahouti Harehdasht, N. Yousefieh, S. Jahandari, and M. Saberian, "Non-linear behaviour of concrete beams reinforced with GFRP and CFRP bars grouted in sleeves," Structures, vol. 23, pp. 87-102, 2020.

[41] R. Park and J. Jang, "Performance improvement of carbon fiber/polyethylene fiber hybrid composites," Journal of Materials Science, vol. 34, 1999.

[42] A. S. Azevedo, J. P. Firmo, J. R. Correia, and C. Tiago, "Influence of elevated temperatures on the bond behaviour between concrete and NSM-CFRP strips," Cement and Concrete Composites, vol. 111, p. 103603, 2020.

[43] R. Sonnenschein, K. Gajdosova, and I. Holly, "FRP composites and their using in the construction of bridges," Procedia Engineering, vol. 161, pp. 477-482, 2016.

[44] L. Alexandre, S. C. Alexandre, and B. E. D. Miranda, "Mechanical properties of glass fiber reinforced polymers members for structural applications," Materials Research, vol. 18, no. 6, pp. 1372-1383, 2015. 
[45] S. Al-Obaidi, Y. M. Saeed, and F. N. Rad, "Flexural strengthening of reinforced concrete beams with NSMCFRP bars using mechanical interlocking," Journal of Building Engineering, vol. 31, p. 101422, 2020.

[46] Z. Huang, Y. Zhao, J. Zhang, and Y. Wu, "Punching shear behaviour of concrete slabs reinforced with CFRP grids," Structures, vol. 26, pp. 617-625, 2020.

[47] M. H. Meisami, D. Mostofinejad, and H. Nakamura, "Punching shear strengthening of two-way flat slabs using CFRP rods," Composite Structures, vol. 99, pp. 112-122, 2013.

[48] B. Zhang, R. Masmoudi, and B. Benmokrane, "Behaviour of one-way concrete slabs reinforced with CFRP grid reinforcements," Construction and Building Materials, vol. 18, no. 8, pp. $625-635,2004$.

[49] L. K. Amaireh and A. Al-Tamimi, "Optimum configuration of CFRP composites for strengthening of reinforced concrete beams considering the contact constraint," Procedia Manufacturing, vol. 44, pp. 350-357, 2020.

[50] T. Siwowski, B. Piątek, P. Siwowska, and A. Wiater, "Development and implementation of CFRP post-tensioning system for bridge strengthening," Engineering Structures, vol. 207, p. 110266, 2020.

[51] B. Ramesh and S. Eswari, "Structural response of GFRP strengthened hybrid fibre reinforced concrete beams," $M a$ terials Today: Proceedings, vol. 33, 2020.

[52] J. M. F. d. Paiva, A. D. N. d. Santos, and M. C. Rezende, "Mechanical and morphological characterizations of carbon fiber fabric reinforced epoxy composites used in aeronautical field," Materials Research, vol. 12, no. 3, pp. 367-374, 2009.

[53] R. A. Hawileh, A. Abu-Obeidah, J. A. Abdalla, and A. AlTamimi, "Temperature effect on the mechanical properties of carbon, glass and carbon-glass FRP laminates," Construction and Building Materials, vol. 75, pp. 342-348, 2015.

[54] Y. Zhou, X. Zheng, F. Xing, L. Sui, Y. Zheng, and X. Huang, "Investigation on the electrochemical and mechanical performance of CFRP and steel-fiber composite bar used for impressed current cathodic protection anode," Construction and Building Materials, vol. 255, 2020.

[55] S. C. Brown, C. Robert, V. Koutsos, and D. Ray, "Methods of modifying through-thickness electrical conductivity of CFRP for use in structural health monitoring, and its effect on mechanical properties-a review," Composites Part A-Applied Science and Manufacturing, vol. 133, 2020.

[56] D. Mostofinejad and S. M. Shameli, "Externally bonded reinforcement in grooves (EBRIG) technique to postpone debonding of FRP sheets in strengthened concrete beams," Construction and Building Materials, vol. 38, pp. 751-758, 2013.

[57] P. Zhang, D. Lei, Q. Ren, J. He, H. Shen, and Z. Yang, "Experimental and numerical investigation of debonding process of the FRP plate-concrete interface," Construction and Building Materials, vol. 235, p. 117457, 2020.

[58] M. Miralami, M. R. Esfahani, and M. Tavakkolizadeh, "Strengthening of circular RC column-foundation connections with GFRP/SMA bars and CFRP wraps," Composites Part B: Engineering, vol. 172, pp. 161-172, 2019.

[59] M. N. Sheikh and F. Légeron, "Performance based seismic assessment of bridges designed according to Canadian Highway Bridge Design Code," Canadian Journal of Civil Engineering, vol. 41, no. 9, pp. 777-787, 2014.

[60] H. Tobbi, A. S. Farghaly, and B. Benmokrane, "Behavior of concentrically loaded fiber-reinforced polymer reinforced concrete columns with varying reinforcement types and ratios," ACI Structural Journal, vol. 111, no. 2, pp. 375-385, 2014.
[61] H. M. Mohamed and B. Benmokrane, "Design and performance of reinforced concrete water chlorination tank totally reinforced with GFRP bars: case study," Journal of Composites for Construction, vol. 18, no. 1, Article ID 05013001, 2014.

[62] M. H. Mohamed, F. Ghrib, A. Hadhood et al., "Efficiency of glass-fiber reinforced-polymer (GFRP) discrete hoops and bars in concrete columns under combined axial and flexural loads," Composites, Part B Engineering, vol. 114, 2017.

[63] A. Hadhood, H. M. Mohamed, B. Benmokrane, A. Nanni, and C. K. Shield, "Assessment of design guidelines of concrete columns reinforced with glass fiber-reinforced polymer bars," ACI Structural Journal, vol. 116, no. 4, pp. 193-207, 2019.

[64] A. H. Ali, M. H. Mohamed, C. Omar, B. Brahim, and G. Faouzi, "Shear resistance of RC circular members with FRP discrete hoops versus spirals," Engineering Structures, vol. 174, pp. 688-700, 2018.

[65] T. Cadenazzi, G. Dotelli, M. Rossini, S. Nolan, and A. Nanni, "Life-cycle cost and life-cycle assessment analysis at the design stage of a fiber-reinforced polymer-reinforced concrete bridge in Florida," Advances in Civil Engineering Materials, vol. 8, no. 2, p. 20180113, 2019.

[66] A. Wiater and T. Siwowski, "Serviceability and ultimate behaviour of GFRP reinforced lightweight concrete slabs: experimental test versus code prediction," Composite Structures, vol. 239, p. 112020, 2020.

[67] V. Dhand, G. Mittal, K. Y. Rhee, S.-J. Park, and D. Hui, “A short review on basalt fiber reinforced polymer composites," Composites Part B: Engineering, vol. 73, pp. 166-180, 2015.

[68] P. Banibayat and A. Patnaik, "Variability of mechanical properties of basalt fiber reinforced polymer bars manufactured by wet-layup method," Materials \& Design (1980-2015), vol. 56, pp. 898-906, 2014.

[69] B. Wei, H. Cao, and S. Song, "Degradation of basalt fibre and glass fibre/epoxy resin composites in seawater," Corrosion Science, vol. 53, no. 1, pp. 426-431, 2011.

[70] X. Wang, Z. Wu, G. Wu, H. Zhu, and F. Zen, "Enhancement of basalt FRP by hybridization for long-span cable-stayed bridge," Composites Part B: Engineering, vol. 44, no. 1, pp. 184-192, 2013.

[71] V. Lopresto, C. Leone, and I. De Iorio, "Mechanical characterisation of basalt fibre reinforced plastic," Composites Part B: Engineering, vol. 42, no. 4, pp. 717-723, 2011.

[72] P. Larrinaga, C. Chastre, H. C. Biscaia, and J. T. San-José, "Experimental and numerical modeling of basalt textile reinforced mortar behavior under uniaxial tensile stress," Materials \& Design, vol. 55, pp. 66-74, 2014.

[73] V. Fiore, G. Di Bella, and A. Valenza, "Glass-basalt/epoxy hybrid composites for marine applications," Materials \& Design, vol. 32, no. 4, pp. 2091-2099, 2011.

[74] T. M. Borhan, "Properties of glass concrete reinforced with short basalt fibre," Materials \& Design, vol. 42, pp. 265-271, 2012.

[75] J. Sim, C. Park, and D. Y. Moon, "Characteristics of basalt fiber as a strengthening material for concrete structures," Composites Part B: Engineering, vol. 36, no. 6-7, pp. 504-512, 2005.

[76] X. Hu and T. Shen, "The applications of the CBF in war industy and civil fields," Hi-Tech Fiber Application, vol. 30, no. 6, pp. 7-13, 2005.

[77] Y. Nakayama, H. Nakai, and T. Kanakubo, "Bond behabior between deformed aramid fiber-reinforced plastic reinforcement and concrete," in Proceedings of the 14th 
World Conference on Earthquake Engineering, Beijing, China, October 2008.

[78] R. E. Wilfong and J. Zimmerman, "Strength and durability characteristics of Kevlar aramid fibre," Applied Polymer Symposia, vol. 31, pp. 1-21, 1977.

[79] M. Saafi and H. Toutanji, "Flexural capacity of prestressed concrete beams reinforced with aramid fiber reinforced polymer (AFRP) rectangular tendons," Construction and Building Materials, vol. 12, no. 5, pp. 245-249, 1998.

[80] S. Bagherpour, Fibre Reinforced $R$ Composites, M. Saleh Hosam El-Din, Ed., p. 167, Springer, Berlin, Germany, 2012.

[81] C. B. Nayak, "Experimental and numerical investigation on compressive and flexural behavior of structural steel tubular beams strengthened with AFRP composites," Journal of King Saud University-Engineering Sciences, 2020.

[82] R. Sakurada, T. Shimomura, K. Maruyama, and S. Matsubara, "Bending behavior of rc beam reinforced with braided aramid FRP bar," in Proceedings of the The 31st Conference on Our World in Concrete and Structures, Singapore, August 2006.

[83] S. Yin, R. Tuladhar, R. A. Shanks et al., "Fiber preparation and mechanical properties of recycled polypropylene for reinforcing concrete," Journal of Applied Polymer Science, vol. 132, 2015.

[84] N. Banthia and V. Cheng, "Shrinkage cracking in polyolefin fiber-reinforced concrete," ACI Structural Journal, vol. 97, no. 4, pp. 432-437, 2000.

[85] N. Eswari, "Ductility response of hybrid fibre reinforced concrete beams," Journal of Urban and Environmental Engineering, vol. 11, no. 2, pp. 174-179, 2017.

[86] D. Jerrett and J. T. Cuddington, "Broadening the statistical search for metal price super cycles to steel and related metals," Resources Policy, vol. 33, no. 4, pp. 188-195, 2008.

[87] V. M. Karbhari and L. Zhao, "Issues related to composite plating and environmental exposure effects on compositeconcrete interface in external strengthening," Composite Structures, vol. 40, 1997.

[88] A. Gharachorlou and A. Ramezanianpour, "Resistance of concrete specimens strengthened with FRP sheets to the penetration of chloride ions," Arabian Journal for Science and Engineering, vol. 35, 2010.

[89] P. Böer, L. Holliday, and T. H.-K. Kang, "Independent environmental effects on durability of fiber-reinforced polymer wraps in civil applications: a review," Construction and Building Materials, vol. 48, pp. 360-370, 2013.

[90] M. A. G. Silva, B. S. da Fonseca, and H. Biscaia, "On estimates of durability of FRP based on accelerated tests," Composite Structures, vol. 116, pp. 377-387, 2014.

[91] D. Zhao, J. Pan, Y. Zhou, L. Sui, and Z. Ye, "New types of steel-FRP composite bar with round steel bar inner core: mechanical properties and bonding performances in concrete," Construction and Building Materials, vol. 242, p. 118062, 2020.

[92] J. W. Schmidt, A. Bennitz, B. Täljsten, P. Goltermann, and H. Pedersen, "Mechanical anchorage of FRP tendons-a literature review," Construction and Building Materials, vol. 32, pp. 110-121, 2012.

[93] H. Zhang, L. He, and G. Li, "Bond failure performances between near-surface mounted FRP bars and concrete for flexural strengthening concrete structures," Engineering Failure Analysis, vol. 56, pp. 39-50, 2015.

[94] T. Uomoto, H. Mutsuyoshi, F. Katsuki, and S. Misra, "Use of fiber reinforced polymer composites as reinforcing material for concrete," Journal of Materials in Civil Engineering, vol. 14, no. 3, pp. 191-209, 2002.

[95] E. Y. Sayed-Ahmed and N. G. Shrive, "A new steel anchorage system for post-tensioning applications using carbon fibre reinforced plastic tendons," Canadian Journal of Civil Engineering, vol. 25, no. 1, pp. 113-127, 1998.

[96] X. Yang, W.-Y. Gao, J.-G. Dai, and Z.-D. Lu, "Shear strengthening of RC beams with FRP grid-reinforced ECC matrix," Composite Structures, vol. 241, p. 112120, 2020.

[97] J. P. Firmo, J. R. Correia, D. Pitta, C. Tiago, and M. R. T. Arruda, "Experimental characterization of the bond between externally bonded reinforcement (EBR) CFRP strips and concrete at elevated temperatures," Cement and Concrete Composites, vol. 60, pp. 44-54, 2015.

[98] J. P. Firmo, J. R. Correia, D. Pitta, C. Tiago, and M. R. T. Arruda, "Bond behavior between near-surfacemounted CFRP strips and concrete at high temperatures," Journal of Composites for Construction, vol. 19, no. 4, 2015.

[99] P. J. Burke, L. A. Bisby, and M. F. Green, "Effects of elevated temperature on near surface mounted and externally bonded FRP strengthening systems for concrete," Cement and Concrete Composites, vol. 35, no. 1, pp. 190-199, 2013.

[100] N. S. Ottosen, "Failure and elasticity of concrete," Danish Atomic Energy Commission, Risoe. Research Establishment, International Atomic Energy Agency, Vienna, Austria, RISO-M-1801, 1975.

[101] G. H. Béguin, "Discussion of "reinforced concrete beams with plates glued to their soffits" by deric john oehlers (august, 1992, vol. 118, No. 8)," Journal of Structural Engineering, vol. 120, no. 4, pp. 1368-1369, 1994.

[102] T. M. Roberts, "Approximate analysis of shear and normal stress concentrations in the adhesive layer of plated RC beams," The Structural Engineer, vol. 67, no. 12, pp. 229-233, 1989.

[103] R. Jones, R. N. Swamy, and A. Charif, "Plate separation and anchorage of reinforced concrete beams strengthened by epoxy-bonded steel plate," Structural Engineer, vol. 66, no. 5, 1988.

[104] J. Sim, H. Oh, and C. Meyer, "Structural assessment of externally strengthened bridge deck panels," Applied Composite Materials, vol. 13, pp. 99-114, 2006.

[105] M. N. Dai, T. K. Chan, and H. K. Cheong, "Brittle failure and bond development length of CFRP-concrete beams," Journal of Composites for Construction, vol. 5, no. 1, pp. 12-17, 2001.

[106] P. Mukhopadhyaya and N. Swamy, "Interface shear stress: a new design criterion for plate debonding," Journal of Composites for Construction, vol. 5, no. 1, pp. 35-43, 2001.

[107] H. F. Isleem, M. Tahir, and Z. Wang, "Axial stress-strain model developed for rectangular RC columns confined with FRP wraps and anchors," Structures, vol. 23, pp. 779-788, 2020.

[108] A. de Diego, Á. Arteaga, and J. Fernández, "Strengthening of square concrete columns with composite materials. Investigation on the FRP jacket ultimate strain," Composites Part B: Engineering, vol. 162, pp. 454-460, 2019.

[109] G. Lin and J. G. Teng, "Advanced stress-strain model for FRP-confined concrete in square columns," Composites Part B: Engineering, vol. 197, p. 108149, 2020.

[110] C. Bakis, A. Ganjehlou, D. Kachlakev et al., Guide for the Design and Construction of Externally Bonded FRP Systems for Strengthening Concrete Structures, p. 440, American Concrete Institute, Farmington Hills, MI, USA, 2002.

[111] Japan Concrete Engineering Series, Recommendations for upgrading of concrete structures with use of continuous fibre 
sheets, Vol. 41, Japan Society of Civil Engineers, Tokyo, Japan, 2001.

[112] A. F. Ashour, S. A. El-Refaie, and S. W. Garrity, "Flexural strengthening of RC continuous beams using CFRP laminates," Cement and Concrete Composites, vol. 26, no. 7, pp. 765-775, 2004.

[113] J. Pan and Y.-F. Wu, "Analytical modeling of bond behavior between FRP plate and concrete," Composites Part B: Engineering, vol. 61, pp. 17-25, 2014.

[114] J. G. Teng, S. T. Smith, J. Yao, and J. F. Chen, "Intermediate crack-induced debonding in RC beams and slabs," Construction and Building Materials, vol. 17, no. 6-7, pp. 447462, 2003.

[115] S. Amiri and S. Behzad Talaeitaba, "Punching shear strengthening of flat slabs with EBROG and EBRIG - FRP strips," Structures, vol. 26, pp. 139-155, 2020.

[116] P. K. V. R. Padalu, Y. Singh, and S. Das, "Out-of-plane flexural behaviour of masonry wallettes strengthened using FRP composites and externally bonded grids: comparative study," Composites Part B: Engineering, vol. 176, p. 107302, 2019.

[117] X. Yang, W.-Y. Gao, J.-G. Dai, Z.-D. Lu, and K.-Q. Yu, "Flexural strengthening of RC beams with CFRP gridreinforced ECC matrix," Composite Structures, vol. 189, pp. 9-26, 2018.

[118] V. M. Karbhari, Use of Composite Materials in Civil Infrastructure in Japan, International Technology Research Institute World Technology Division, Hsinchu, Taiwan, 1998.

[119] J. J. Brunton, L. C. Bank, and M. G. Oliva, "Punching shear failure in double-layer pultruded FRP grid reinforced concrete bridge decks," Advances in Structural Engineering, vol. 15, no. 4, pp. 601-613, 2012.

[120] C. Papanicolaou, T. Triantafillou, and M. Lekka, "Externally bonded grids as strengthening and seismic retrofitting materials of masonry panels," Construction and Building Materials, vol. 25, no. 2, pp. 504-514, 2011.

[121] L. Ding, S. Rizkalla, G. Wu, and Z. S. Wu, Bond Mechanism of Carbon Fiber Reinforced Polymer Grid to Concrete, Springer, Berlin, Germany, 2010.

[122] A. H. Rahman, C. Y. Kingsley, and K. Kobayashi, "Service and ultimate load behavior of bridge deck reinforced with carbon FRP grid," Journal of Composites for Construction, vol. 4, no. 1, pp. 16-23, 2000.

[123] N. Banthia, M. Al-Asaly, and S. Ma, "Behavior of concrete slabs reinforced with fiber-reinforced plastic grid," Journal of Materials in Civil Engineering, vol. 7, no. 4, pp. 252-257, 1995.

[124] X. Wang, Z. Peng, Z. Wu, and S. Sun, "High-performance composite bridge deck with prestressed basalt fiber-reinforced polymer shell and concrete," Engineering Structures, vol. 201, p. 109852, 2019.

[125] Q. Wu, S. Xiao, and K. Iwashita, "Experimental study on the interfacial shear stress of RC beams strengthened with prestressed BFRP rod," Results in Physics, vol. 10, pp. 427433, 2018.

[126] T. Lou and T. L. Karavasilis, "Numerical evaluation of prestressed steel-concrete composite girders with external FRP or steel tendons," Journal of Constructional Steel Research, vol. 162, p. 105698, 2019.

[127] M. Aslam, P. Shafigh, M. Z. Jumaat, and S. N. R. Shah, "Strengthening of RC beams using prestressed fiber reinforced polymers-a review," Construction and Building Materials, vol. 82, no. may 1, pp. 235-256, 2015.
[128] A. H. J. M. Vervuurt, N. Kaptijn, and W. B. Grundlehner, "Carbon-based tendons in the dintelhaven bridge, The Netherlands," Structural Concrete, vol. 4, no. 1, pp. 1-11, 2003.

[129] T. Noro and T. Hojo, "Application of carbon-fiber cables for cable-supported structures," IABSE Symposium Report, vol. 86, no. 7, 2002.

[130] B. Gaubinger and J. Kollegger, "Development of an anchorage system for CFRP tendons," IABSE Symposium Report, vol. 86, no. 7, pp. 95-102, 2002.

[131] J. Horvatits and J. Kollegger, External CFRP Tendons for Bridge Strengthening in Austria, ICE Publishing, London, UK, 2005.

[132] H. Nordin and B. Täljsten, "Strengthening of concrete structures by external prestressing," in Proceedings of the Third International Conference on Bridge Maintenance, Safety and Management, Porto, Portugal, July 2006.

[133] F. Matta, A. Nanni, A. Abdelrazaq, D. Gremel, and R. Koch, "Externally post-tensioned carbon FRP bar system for deflection control," Construction and Building Materials, vol. 23, no. 4, pp. 1628-1639, 2009.

[134] C. Macdougall, M. Green, and L. Amato, "CFRP tendons for the repair of post-tensioned, unbonded concrete buildings," Journal of Performance of Constructed Facilities, vol. 25, no. 3, pp. 149-157, 2009.

[135] A. Nanni, C. E. Bakis, and T. E. Boothby, "Test methods for FRP-concrete systems subjected to mechanical loads: state of the art review," Journal of Reinforced Plastics and Composites, vol. 14, no. 6, pp. 524-558, 1995.

[136] Y. Xiang, B. Miller, A. Nanni, and E. Charles, "Bakis. Characterization of CFRP rods used as near-surface mounted reinforcement," in Proceedings of the 8th International Conference on Structural Faults and Repair, Mainz, Germany, September 1999.

[137] Z. Yu, "Behaviour of concrete bridge deck slabs strengthened with NSM FRP bars," in Proceedings of the International Conference on Fibre-Reinforced Polymer Composites in Civil Engineering, Hong Kong, China, December 2016.

[138] G. Foret and O. Limam, "Experimental and numerical analysis of RC two-way slabs strengthened with NSM CFRP rods," Construction and Building Materials, vol. 22, no. 10, pp. 2025-2030, 2008.

[139] O. Asplund, "Strengthening bridge slabs with grouted reinforcement," Journal of American Concrete Institute, vol. 20, no. 6, pp. 397-406, 1949.

[140] P. Casadei, N. Galati, R. Parretti, A. Nanni, and P. Galati, Strengthening of a Bridge Using Two FRP Technologies, pp. 219-238, ACI Publication, Farmington Hills, MI, USA, 2003.

[141] T. Alkhrdaji, A. Nanni, G. Chen, and M. Barker, "Upgrading the transportation infrastructure: solid RC decks strengthened with FRP," Concrete International, vol. 21, no. 10, 1999.

[142] L. De Lorenzis, A. Rizzo, and A. La Tegola, "A modified pullout test for bond of near-surface mounted FRP rods in concrete," Composites Part B: Engineering, vol. 33, no. 8, pp. 589-603, 2002.

[143] T. Martin, S. Taylor, D. Robinson, and D. Cleland, "Basalt fibre reinforced polymer bar strengthening compared to arching actions within slabs," in Proceedings of the 6th International Conference on FRP Composites in Civil Engineering, CICE, Rome, Italy, June 2012.

[144] Q. Wang, T. Li, H. Zhu, W. Su, and X. Hu, "Bond enhancement for NSM FRP bars in concrete using different 
anchorage systems," Construction and Building Materials, vol. 246, p. 118316, 2020.

[145] Q. Wang, H. Zhu, T. Li, G. Wu, and X. Hu, "Bond performance of NSM FRP bars in concrete with an innovative additional ribs anchorage system: an experimental study," Construction and Building Materials, vol. 207, pp. 572-584, 2019.

[146] C. Barris, P. Sala, J. Gómez, and L. Torres, "Flexural behaviour of FRP reinforced concrete beams strengthened with NSM CFRP strips," Composite Structures, vol. 241, p. 112059, 2020.

[147] I. A. Sharaky, L. Torres, J. Comas, and C. Barris, "Flexural response of reinforced concrete (RC) beams strengthened with near surface mounted (NSM) fibre reinforced polymer (FRP) bars," Composite Structures, vol. 109, pp. 8-22, 2014.

[148] S. S. Zhang, T. Yu, and G. M. Chen, "Reinforced concrete beams strengthened in flexure with near-surface mounted (NSM) CFRP strips: current status and research needs," Composites Part B: Engineering, vol. 131, pp. 30-42, 2017.

[149] M. Ibrahim, T. Wakjira, and U. Ebead, "Shear strengthening of reinforced concrete deep beams using near-surface mounted hybrid carbon/glass fibre reinforced polymer strips," Engineering Structures, vol. 210, p. 110412, 2020.

[150] S. S. Zhang and J. G. Teng, "Finite element prediction of plate-end cover separation in FRP-strengthened RC beams," in Proceedings of the International Symposium on Structural Engineering, Orlando, FL, USA, May 2010.

[151] A. Michael, C. O’Neill, and M. Ansley, “Bridge decks strenthened with near-surface mounted bars embedded in cement-based grout," Composites and Polycon, vol. 2, 2007.

[152] M. Hosseini, S. Dias, and J. Barros, "Behaviour of RC slabs flexurally strengthened with presressed NSM CFRP laminates," Joaquim Barros and Jose Sena-Cruz, 2013.

[153] D. Lee and L. Cheng, "Assessing the strengthening effect of various near-surface-mounted FRP reinforcements on concrete bridge slab overhangs," Journal of Composites for Construction, vol. 15, no. 4, pp. 615-624, 2011.

[154] S. Shahriari and H. Naderpour, "Reliability assessment of shear-deficient reinforced concrete beams externally bonded by FRP sheets having different configurations," Structures, vol. 25, pp. 730-742, 2020.

[155] S. S. Choobbor, R. A. Hawileh, A. Abu-Obeidah, and J. A. Abdalla, "Performance of hybrid carbon and basalt FRP sheets in strengthening concrete beams in flexure," Composite Structures, vol. 227, p. 111337, 2019.

[156] O. R. Abuodeh, J. A. Abdalla, and R. A. Hawileh, "Prediction of shear strength and behavior of RC beams strengthened with externally bonded FRP sheets using machine learning techniques," Composite Structures, vol. 234, p. 111698, 2020.

[157] A. Hosny, H. Shaheen, A. Abdelrahman, and T. Elafandy, "Performance of reinforced concrete beams strengthened by hybrid FRP laminates," Cement and Concrete Composites, vol. 28, no. 10, pp. 906-913, 2006.

[158] J. Qi, Z. J. Ma, J. Wang, and Y. Bao, "Post-cracking shear behaviour of concrete beams strengthened with externally prestressed tendons," Structures, vol. 23, pp. 214-224, 2020.

[159] A. Rizzo and L. De Lorenzis, "Modeling of debonding failure for RC beams strengthened in shear with NSM FRP reinforcement," Construction and Building Materials, vol. 23, no. 4, pp. 1568-1577, 2009.

[160] C. Chen, Y. Yang, J. Yu et al., "Eco-friendly and mechanically reliable alternative to synthetic FRP in externally bonded strengthening of RC beams: natural FRP," Composite Structures, vol. 241, p. 112081, 2020.
[161] L. Huang, B. Yan, L. Yan, Q. Xu, H. Tan, and B. Kasal, "Reinforced concrete beams strengthened with externally bonded natural flax FRP plates," Composites Part B: Engineering, vol. 91, pp. 569-578, 2016.

[162] D. Gao, D. Fang, P. You, G. Chen, and J. Tang, "Flexural behavior of reinforced concrete one-way slabs strengthened via external post-tensioned FRP tendons," Engineering Structures, vol. 216, p. 110718, 2020.

[163] R. El-Hacha and S. H. Rizkalla, "Near-surface-mounted fiber-reinforced polymer reinforcements for flexural strengthening of concrete structures," ACI Structural Journal, vol. 101, no. 5, pp. 717-726.

[164] A. Bilotta, F. Ceroni, E. Nigro, and M. Pecce, "Efficiency of CFRP NSM strips and EBR plates for flexural strengthening of RC beams and loading pattern influence," Composite Structures, vol. 124, pp. 163-175, 2015.

[165] G. M. Dalfré and J. A. O. Barros, "Flexural strengthening of RC continuous slab strips using NSM CFRP laminates," Advances in Structural Engineering, vol. 14, no. 6, pp. 1223-1245, 2011.

[166] Y.-F. Wu, X.-S. Xu, J.-B. Sun, and C. Jiang, "Analytical solution for the bond strength of externally bonded reinforcement," Composite Structures, vol. 94, no. 11, pp. 3232-3239, 2012.

[167] Y. Wu, Z. Zhou, Q. Yang, and W. Chen, "On shear bond strength of FRP-concrete structures," Engineering Structures, vol. 32, no. 3, pp. 897-905, 2010.

[168] J. G. Teng, H. Yuan, and J. F. Chen, "FRP-to-concrete interfaces between two adjacent cracks: theoretical model for debonding failure," International Journal of Solids and Structures, vol. 43, no. 18-19, pp. 5750-5778, 2006.

[169] R. Seracino, M. R. Raizal Saifulnaz, and D. J. Oehlers, "Generic debonding resistance of EB and NSM plate-to-concrete joints," Journal of Composites for Construction, vol. 11, no. 1, pp. 62-70, 2007.

[170] X. Z. Lu, L. P. Ye, J. G. Teng, and J. J. Jiang, "Meso-scale finite element model for FRP sheets/plates bonded to concrete," Engineering Structures, vol. 27, no. 4, pp. 564-575, 2005.

[171] J.-F. Chen and J. G. Teng, "Anchorage strength models for FRP and steel plates bonded to concrete," Journal of Structural Engineering, vol. 127, 2001.

[172] L. C. Hollaway, "A review of the present and future utilisation of FRP composites in the civil infrastructure with reference to their important in-service properties," Construction and Building Materials, vol. 24, no. 12, pp. 24192445, 2010.

[173] Y. H. Mugahed Amran, R. Alyousef, R. S. M. Rashid, H. Alabduljabbar, and C.-C. Hung, "Properties and applications of FRP in strengthening RC structures: a review," Structures, vol. 16, pp. 208-238, 2018.

[174] R. Selzer and K. Friedrich, "Mechanical properties and failure behaviour of carbon fibre-reinforced polymer composites under the influence of moisture," Composites Part A: Applied Science and Manufacturing, vol. 28, no. 6, pp. 595604, 1997.

[175] R. Selzer and K. Friedrich, "Inluence of water up-take on interlaminar fracture properties of carbon fibre-reinforced polymer composites," Journal of Materials Science, vol. 30, no. 2, pp. 334-338, 1995.

[176] L. Kumosa, B. Benedikt, D. Armentrout, and M. Kumosa, "Moisture absorption properties of unidirectional glass/ polymer composites used in composite (non-ceramic) insulators," Composites Part A: Applied Science and Manufacturing, vol. 35, no. 9, pp. 1049-1063, 2004. 
[177] R. Andrews, E. Grulke, and G. Kimber, Mechanical Properties of Carbon Fiber Composites for Environmental Applications, American Chemical Society, Washington, DC, USA, 1996.

[178] L. Hollaway, A. Thorne, and R. Quantrill, "Experimental and analytical investigation of FRP strengthened beam response: Part I," Magazine of Concrete Research, vol. 48, pp. 331-342, 1996.

[179] M. Ali, L. Hollaway, D. Oehlers, R. Quantrill, and A. Thorne, "Predictions of the maximum plate end stresses of FRP strengthened beams: Part II," Magazine of Concrete Research, vol. 50, pp. 91-92, 1998.

[180] A. M. Ceci, J. R. Casas, and M. Ghosn, "Statistical analysis of existing models for flexural strengthening of concrete bridge beams using FRP sheets," Construction and Building Materials, vol. 27, no. 1, pp. 490-520, 2012.

[181] R. El-Hacha and F. Oudah, "Postfatigue monotonic behavior of RC beams strengthened with prestressed NSM CFRP strips: ductility evaluation," Journal of Composites for Construction, vol. 18, 2013.

[182] A. A. Mufti, J. P. Newhook, and G. Tadros, "Deformability versus ductility in concrete beams with FRP reinforcement," in Proceedings of the International Conference on Advanced Composite Materials in Bridges \& Structures, Montréal, Canada, August 1996. 